\title{
Extracellular Genomic Biomarkers of Osteoarthritis
}

\author{
Emma Budd $^{\text {a, b }}$, Giovanna Nalesso ${ }^{\mathrm{b}}$, Ali Mobasheri ${ }^{\mathrm{a}, \mathrm{b}, \mathrm{c}}$
}

${ }^{a}$ The D-BOARD European Consortium for Biomarker Discovery, School of Veterinary Medicine, Guildford, University of Surrey, GU2 7XH, United Kingdom

${ }^{b}$ Department of Veterinary Pre-Clinical Sciences, School of Veterinary Medicine, Faculty of Health and Medical Sciences, University of Surrey, Guildford, GU2 7XH, United Kingdom

${ }^{c}$ Arthritis Research UK Centre for Sport, Exercise and Osteoarthritis, Queen's Medical Centre, Nottingham, NG7 2UH, United Kingdom

* Address correspondence and reprint requests to: Dr Emma Budd, School of Veterinary Medicine, University of Surrey, Guildford, GU2 7AL, United Kingdom

E-mail addresses:

e.budd@surrey.ac.uk (Emma Budd)

g.nalesso@surrey.ac.uk (Giovanna Nalesso)

a.mobasheri@surrey.ac.uk (Ali Mobasheri)

Authors' contributions: E.B. conceived, drafted and edited the manuscript. G.N. edited and approved the submission. A.M. edited and approved the submission. All authors contributed to data interpretation and manuscript preparation and approved the final version submitted.

Acknowledgements: The research leading to these results was funded by the European Commission Framework 7 programme (EU FP7; HEALTH.2012.2.4.5-2, project number 305815; Novel Diagnostics and Biomarkers for Early Identification of Chronic Inflammatory Joint Diseases). This project has also received partial support from the Innovative Medicines Initiative Joint Undertaking under grant agreement No. 115770, resources of which are composed of financial contribution from the European Union's Seventh Framework programme (FP7/2007-2013) and EFPIA companies' in-kind contribution. The funders had no role in study design, data collection and analysis, decision to publish, or preparation of the manuscript. 
Disclosure statement: The authors declare that they have no competing interests. This paper was written by the authors within the scope of their academic and research positions. None of the authors have any relationships that could be construed as biased or inappropriate. A. Mobasheri is coordinator of the D-BOARD Consortium funded by the European Commission Framework 7 programme (EU FP7; HEALTH.2012.2.4.5-2, project number 305815; Novel Diagnostics and Biomarkers for Early Identification of Chronic Inflammatory Joint Diseases) and member of the Arthritis Research UK Centre for Sport, Exercise, and Osteoarthritis, funded by Arthritis Research UK (grant reference numbers: 20194 and 21595). A.M. is a member of the Applied Public-Private Research enabling OsteoArthritis Clinical Headway (APPROACH) consortium, a 5-year project funded by the European Commission's Innovative Medicines Initiative. APPROACH is a public-private partnership directed towards osteoarthritis biomarker development through the establishment of a heavily phenotyped and comprehensively analysed longitudinal cohort. 


\begin{abstract}
Introduction

Osteoarthritis (OA), a chronic, debilitating and degenerative disease of the joints, is the most common form of arthritis. The seriousness of this prevalent and chronic disease is often overlooked. Disease modifying OA drug (DMOAD) development is hindered by the lack of soluble biomarkers to detect OA early. The objective of OA biomarker research is to identify early OA prior to the appearance of radiographic signs and the development of pain.
\end{abstract}

\title{
Areas covered
}

This review has focused on extracellular genomic material that could serve as biomarkers of OA. Recent studies have examined the expression of extracellular genomic material such as miRNA, IncRNA, snoRNA, mRNA and cell-free DNA (cfDNA), which are aberrantly expressed in the body fluids of OA patients. Changes in genomic content of peripheral blood mononuclear cells (PBMCs) in OA could also function as biomarkers of OA.

\section{Expert commentary}

There is an unmet need for soluble biomarkers for detecting and then monitoring OA disease progression. Extracellular genomic material research may also reveal more about the underlying pathophysiology of OA. Minimally-invasive liquid biopsies such as synovial fluid and blood sampling of genomic material may be more sensitive over radiography in the detection, diagnosis and monitoring of $\mathrm{OA}$ in the future.

\section{Key words}

Osteoarthritis; Extracellular; Genomic biomarkers; Body fluids; Liquid biopsy; ncRNA; miRNA; cfDNA; mRNA; extracellular nucleic acid carriers 


\section{The current perspective on osteoarthritis}

Osteoarthritis (OA) is a chronic and debilitating disease of the joints which is more prevalent than rheumatoid arthritis (RA) and any other arthritic disease [1]. Osteoarthritis (OA) is characterised by progressive deterioration of hyaline cartilage concomitant with changes in surrounding tissues including ligaments, synovium and subchondral bone, resulting in defective integrity of affected articular joints or the spine [2]. OA is classified as a low-grade yet chronic inflammatory disease, with inflammation having a role in many of the associated pathologic changes [3]. Articular cartilage is alymphatic, aneural and avascular, with non-proliferative and non-migratory resident chondrocytes, factors which are likely to contribute the development of $\mathrm{OA}$ in part due to the limited capacity that articular cartilage has for endogenous regeneration [4]. OA is a heterogeneous disease which can be driven by different underlying factors. Phenotypic subgroups include a traumatic injury driven phenotype, an ageing driven phenotype, a synovitis-inflammatory driven phenotype, a subchondral bone phenotype, a cartilage driven phenotype and a metabolic phenotype [1]. The most common risk factors for OA include prior joint injury, age, sex, genetic predisposition and mechanical factors such as malalignment [5].

Not only is OA the most common form of arthritis [6], it is the most common disease of the joints [7]. It has been estimated that approximately $33 \%$ of the UK's population aged over 45 have sought treatment for OA [8]. OA is part of a wider group of diseases which cumulatively are known as musculoskeletal conditions. In 2015 in the UK, musculoskeletal disorders remained to be the leading cause of years lived with disability and an estimated 30.8 million working days were lost in 2016 due to a musculoskeletal condition [8]. In 2013/14 musculoskeletal conditions were accountable for the $3^{\text {rd }}$ largest area of national health care (NHS) programme spending, costing $£ 4.7$ billion [8]. With an ageing population and increasing life expectancy the burden of OA will only increase, which poses an unmet need for the development of new therapies, preventative measures and the identification of sensitive biomarkers for OA diagnosis.

Despite OA being the most common form of arthritis, OA still remains to gain recognition as a serious disease. It has been reported that $78 \%$ of people living with arthritis agreed that society doesn't understand their condition because it doesn't appear as if their condition is serious [8]. In December 2016 the Pre-competitive Consortium for Osteoarthritis (PCCOA) of the Osteoarthritis Research Society International (OARSI) submitted a white paper to the Food and Drug Administration (FDA) in order to attract the attention of the FDA and policy makers to understand the need for effective therapies for OA [9]. The submission of the white paper was as a result of OA experts to portray the seriousness of this chronic and prevalent disease, highlighting the economic burden of OA upon society and the detrimental effects of OA on quality of life, which may deny OA sufferers the right to healthy ageing and basic human rights which are outlined in the United Nations Charter for Rights of Persons with Disability [9]. The white paper was submitted to encourage the development of global and national 
health policies to address the increasing burden of OA and encourage drug development towards identifying disease modifying osteoarthritis drugs (DMOADs). Drug and biomarker development are interdependent, therefore DMOAD development is dependent on sensitive biomarkers which can detect and predict disease progression [10].

\section{Limitations in diagnosing osteoarthritis}

In an era where the use of biomarker analysis to confirm or assess disease state is rapidly advancing, OA lacks the use of any soluble biomarker for diagnosis in the clinical setting. To identify individuals with early-onset OA a screening method to detect biomarkers from body fluid could help in the early diagnosis, and in the future, utilised in companion with a therapy in the treatment of the disease. Radiographs and joint imaging techniques, which are currently routinely used for a diagnosis of OA, do not measure dynamic changes in the joint and are usually implemented when $\mathrm{OA}$ is symptomatic at which point OA has progressed to advanced stages of the disease [11]. Radiography is the most common imaging modality to assess OA, with the use of radiographic grading or scoring classification systems to classify stages of OA [12]. One of the most commonly used radiographic definitions of OA is the Kellgren and Lawrence (KL) classification which grades the whole joint with a score from 0 to 4 , with grade 0 as no $\mathrm{OA}$ and grade 4 as severe $\mathrm{OA}$. The $\mathrm{KL}$ classification is based on radiographic observation of joint space narrowing, marginal osteophytes, subchondral bone sclerosis and bone shape alteration [12]. While imaging techniques such as radiography can detect and monitor structural changes to the joint, giving an indication of disease stage, the rate of OA development and disease progression cannot be evaluated. Imaging techniques can classify OA by structural change only, a KL score of 0 may indicate no OA, but molecular changes at the cellular level may have occurred, for which there is no current method of detection. Joint imaging techniques can only assess structural change at which point OA development is irreversible. A requirement to define and detect the changes which occur during OA disease initiation is needed for which there is a requirement for a sensitive biomarker that can detect and diagnose early-onset $\mathrm{OA}$ and monitor disease progression.

A compounding limitation in OA diagnosis is the range in symptomology which accompanies the disease in different individuals. Asymptomatic OA is a common phenomenon in which disease progression continues with a lack of symptoms in some patients [13]. Knee pain, for example, can be a symptom of OA, but is an imprecise indicator for OA which may not be necessarily correlated with radiographic findings, likewise radiographic knee OA is an imprecise indicator that knee pain will be present. OA has been found to be absent in individuals following radiography despite knee pain suggestive of OA and OA has been found to be present through compounding radiographic evidence in individuals that are asymptomatic [14]. There is no defining risk profile which can predict if an individual has significant damage to cartilage, if an individual has asymptomatic OA, if an individual 
will develop OA or what the progression of destruction to articular cartilage and the joint will be or the rate of OA progression [15].

OA is often not diagnosed until late stages, after significant, destructive and irreparable damage to the joint has already occurred. It has been suggested that molecular indicators exist long before radiographic evidence indicates the presence of OA and it has been estimated that the OA process begins 20 years before OA is detected by radiographic joint space narrowing (JSN) [16]. The issue lies with the diagnosis of OA, clinically detectable $\mathrm{OA}$ is currently confirmed by magnetic resonance imaging (MRI), ultrasound, nuclear medicine bone scans and/or radiography, but currently there is no method to detect biomarkers from extracellular body fluids. Early-stage OA has been defined and involves structural changes to the cartilage [17]. Ryd et al have attempted to define a stage in the OA disease process prior to early-stage OA known as pre-OA. Pre-OA is defined as the preclinical stage in OA whereby OA has been established for a length of time at the cellular level only, prior to early-stage OA which is distinguished by changes in cartilage structure [18]. Ryd et al suggest that the definition of pre-OA should be: 'A knee exhibiting one or many risk factors without pain, normal standing radiographs, no structural changes on arthroscopy or standard MRI, this is, before early OA can be diagnosed' [18]. Preventative measures should be applied at the pre-OA stage to forestall the onset of OA, but first, this stage needs to be identified in individuals.

When discussing the development of biomarkers, it is important to highlight that the identified biomarker/s will be anticipated to be utilised in screening for OA, therefore the method of how potential biomarkers are isolated from the body must be minimally invasive. Other than in arthroscopic debridement, articular cartilage biopsy is not advocated in the clinic to investigate disease status because articular cartilage does not regenerate. The evaluation of extracellular body fluids including synovial fluid, blood, plasma, serum and urine are of interest in identifying a soluble OA biomarker due their relative ease in being isolated from the body [19].

In recent years much of OA biomarker research has focused on proteomic techniques [2]. The view exists that proteomic approaches are advantageous over nucleic acid expression profiling because there is not the potential disconnection that can occur between gene expression and protein expression levels [20] as a result of post-translational modification. The secretome is comprised of secreted proteins and reflects the health of cells in real time [21]. Recent attention has turned to utilising proteomic techniques to identify proteins in the secretome of articular cartilage models of OA, as a potential indicator of disease biomarkers which may be present in the synovial fluid or blood in OA [22]. Proteomic profiling has focused on body fluids from OA patients in the search for a biomarker which is inherent to OA [2332]. The perception exists that extracellular genomic material is unstable as a result of harsh extracellular environments which may have contributed to a lack of focus on the extracellular environment for OA genomic biomarker discovery. 
The International Conference on Harmonisation (ICH) Topic 15 defined a genomic biomarker as 'A measurable DNA and/or RNA characteristic that is an indicator of normal biologic processes, pathogenic processes, and/or response to therapeutic or other interventions' [33]. A genomic biomarker includes measurements of gene expression, gene function and regulation of a gene and can include DNA/RNA characteristics such as SNPs, haplotypes, variability of short sequence repeats, DNA modifications, copy number variations, deletions or insertions of (a) single nucleotide(s), cytogenetic rearrangements, RNA sequences, RNA processing, RNA expression levels and miRNA levels [33]. Pre-OA which is asymptomatic, established at the cellular level and not accompanied by structural changes and therefore undetectable by radiography, requires a method of detection before structural changes ensue [34]. Extracellular genomic material originates from the intracellular environment and may be more informative than extracellular matrix proteins with regards to the intracellular changes which occur prior to the onset of structural changes in OA. Not only could genomics identify genomic biomarkers of OA but also reveal more about the underlying cellular pathophysiology.

\section{Emerging extracellular genomic biomarkers of osteoarthritis}

An extensive array of RNAs have been suggested to exist within extracellular spaces and analysis of sequencing data from plasma-derived RNA identified 1,192 human extracellular RNA including miRNAs, piRNAs and snRNAs [35]. Extracellular vesicles (EVs) have been found to contain DNA, mRNA and subsets of ncRNA [36]. Ubiquitous ribonucleases present in body fluids degrade extracellular RNA [37], but exosomal-derived RNA has been shown to remain stable following RNase A treatment [38]. Extracellular miRNA and potentially other classes of RNA may remain stable in extracellular nuclease-rich environments as a result of extracellular carriers such as exosomes, microvesicles, apoptotic bodies, lipoproteins or protein complexes [39]. In addition to extracellular carrier-associated nucleic acids, cfDNA not associated with any carrier exists in the extracellular environment [40]. Table 1 lists and Figure 1 illustrates both extracellular carrier-associated and extracellular carrier-free genomic material which have the potential to serve as genomic biomarkers in OA.

\subsection{Functional non-coding RNA (ncRNA) in osteoarthritis}

The genome contains protein-coding DNA sequences that are transcribed to produce messenger RNA (mRNA) which in turn are translated to polypeptide sequences, and non-coding DNA, sequences some of which are transcribed to functional RNA sequences but are not translated into polypeptides (Figure 2). $1-2 \%$ of the human genome encodes proteins [41], with the other $98-99 \%$ of the human genome comprising non-coding DNA. Important to note is the distinction between functional non-coding DNA, which includes DNA sequences for example cis-regulatory elements, scaffold/matrix (S/MAR) attachment regions, introns, telomeres and DNA which encodes genes for non-coding RNA, and, nonfunctional non-coding DNA, which has no known function [42]. Regardless of the exact proportion of 
functional non-coding genomic DNA, there exists a proportion which is transcribed into functional RNA (ncRNA) which includes small nuclear RNA (snRNA), transfer RNA (tRNA), ribosomal RNA (rRNA), small nucleolar RNA (snoRNA), microRNA (miRNA), piwi-interacting RNA (piRNA), circular RNA (circRNA) and long non-coding RNA (lncRNA) [43]. Definitions of functional ncRNA are described in Table 2.

NcRNAs can be classified into two groups. NcRNAs that are constitutively expressed and have infrastructural or housekeeping functions, involved in translation, RNA splicing and DNA replication, include tRNA, rRNA and snRNA. While ncRNAs such as miRNA, piRNA and lncRNA which may haves roles in gene expression regulation, classified as regulatory ncRNAs, can themselves be differentially expressed [44]. Diseases have been attributed to perturbation in protein coding gene expression, focus has now turned to looking at the role that ncRNAs may have in disease. The expression of ncRNAs, like mRNA and protein, can be quantified which offers the potential to measure subsets of ncRNAs as indicators of disease state and therefore ncRNAs may serve as genomic biomarkers. Dysregulation of ncRNAs have been observed in tumorigenesis and in cardiovascular, autoimmune, monogenic, neurological, developmental and imprinting disorders [45]. Subsets of ncRNAs have been detected and remain stable in body fluids [46], thus circulating ncRNAs may qualify as potential biomarkers for OA. Discussed below are some of the ncRNAs that have been identified in extracellular fluids in OA.

\subsubsection{MicroRNA}

MicroRNA (miRNA) are single stranded ncRNA of approximately 22 nucleotides in length. MiRNA function by binding to locations within mRNA, typically within the 3'UTR, following RNA transcription [47]. The binding of miRNA to mRNA, in the cytoplasm, prevents mRNA translation in the synthesis of protein. MiRNA is therefore capable of down-regulating protein expression through effective mRNA targeting [48]. MiRNA research has focused on identification of intracellular miRNA, given that miRNA exert their function of down-regulating protein expression in the cell cytoplasm.

Numerous studies have shown the differential expression of different miRNAs from OA cartilage; the expression of miR-140 [49], miR-125b [50], miR-210 [51], miR-222 [52], miR-199a* [53], miR-588 [54], miR-411 [55], miR-105 [56], miR-502-5p [57] have been shown to be down-regulated in human OA chondrocytes and/or cartilage and the expression of miR-146b [4], miR-181b [58], miR-30a [59], miR-455 [60], miR-30b [61], miR-16-5p [62], miR-146a [4,63] have been shown to be up-regulated in human OA chondrocytes and/or cartilage. However, differential miRNA expression in cartilage-centric OA studies does not prove useful in identifying a non-invasive extracellular miRNA biomarker for diagnostic purposes.

Weber at al identified miRNA in 12 body fluids, including breast milk, amniotic fluid, saliva, plasma, tears, urine cerebrospinal fluid, colostrum, seminal fluid, peritoneal fluid and pleural fluid [64]. Release 
of miRNAs into cell culture media has been correlated with cell death and damage in specific tissues has been shown to result in an increase in the level of tissue specific miRNAs in circulation [65]. But, miRNA may be more than by-products of cell apoptosis or necrosis [66] and may also have a potential role in extracellular cell-cell communication [65]. Expression of stable extracellular miRNA could prove useful as a biomarker in OA.

\section{Synovial Fluid}

The concentration of miR-16, miR-146a, miR-155 and miR-223 were found to be significantly higher in synovial fluid from RA patients compared to the synovial fluid from knee OA patients [67]. An assessment of miR-16, miR-146a, miR-155 and miR-223 concentration could be diagnostic in discriminating knee OA from RA. MicroRNA profiling of non-OA and knee OA synovial fluid-derived EVs from males and females identified miR-504-3p as the only miRNA to be expressed in both genders, which indicates the potential need to examine miRNAs as biomarkers of OA by gender segregation [68]. Validation with qPCR of randomly selected miRNAs observed a significant down-regulation of miR-26a-5p, miR-146a-5p and miR-6821-3p in female knee OA synovial fluid-derived EVs, consistent with the miRNA microarray expression results [68], indicating the use of these microRNAs as diagnostic biomarkers in female knee OA.

MicroRNA profiling and follow-up qPCR validation of synovial fluid from patients with early stage radiographic knee OA compared with the synovial fluid of patients with late stage radiographic knee OA revealed significant elevation of miR-23a-3p, miR-24-3p, miR-27a-3p, miR-27b-3p, miR29c-3p, miR-34a-5p, miR-186-5p and miR-378a-5p in late-stage OA [69]. An assessment of the expression of these miRNAs may therefore give an indication of OA progression. Treatment of synovial explants derived from patients with knee OA, with IL-1 $\beta$, resulted in the significant up-regulation of miR-23a$3 p$ and miR-27b-3p, indicating that miR-23a-3p and miR-27b-3p could serve as biomarkers of inflammatory induced knee OA [69]. Similarly, miR-140 expression analysis was conducted on synovial fluid from patients that had radiographic mild, moderate and severe OA and compared to the synovial fluid of patients with no OA. Expression of miR-140 was found to be down-regulated with increasing radiographic severity of OA [70]. Expression of synovial fluid-derived extracellular miR140 could serve as a biomarker of OA progression.

\section{Components of blood}

The serum from individuals with OA-related knee and/or hip arthroplasty was compared to the serum from individuals without arthroplasty for miRNA expression. Let-7e was found to be significantly down-regulated in patients with OA-related knee and/or hip arthroplasty and was also found to be continuously decreased with increasing number of hip and/or joint replacement surgeries [71]. Expression of serum-derived Let-7e could serve as a biomarker for severe hip or knee OA. 
Human TaqMan miRNA array and follow-up qPCR validation of total RNA from the plasma of patients with primary knee OA and patients without OA identified significant up-regulation of 10 miRNAs in OA plasma, including miR-16, miR-146a, miR-29c, miR-93, miR-126, miR-184, miR-186, miR-195, miR-345 and miR-885-5p [72], indicating their use as biomarkers of knee OA. Total RNA isolated from the plasma of patients with knee OA was compared to healthy controls. The expression of miR-19b-3p, miR-122-5p, miR-486-5p and miR-92a-3p were found to be significantly up-regulated in the plasma of OA patients. Univariate and multivariate logistic analysis identified miR-19-3p, miR-122-5p and miR486-5p to be independent factors for risk of knee OA. ROC curve analysis revealed that a combination of miR-19-3p, miR122-5p and miR-486-5p resulted in a high diagnostic value for knee OA, indicating that the combined measurement of all 3 extracellular miRNAs from plasma could serve as soluble genomic biomarkers for knee OA [73].

Another source of miRNA is from cells which reside within the peripheral blood. The expression of miR-146a, miR-155, miR-181a and miR-223 were found to be significantly up-regulated in peripheral blood mononuclear cells (PBMCs) from both, patients with knee OA and in patients with RA, compared to PBMCs from healthy controls. miR-146a, miR-155 and miR-223 were also observed to be significantly up-regulated in PBMCs from patients with RA compared to PBMCs from patients with knee OA [74]. An assessment of miR-146a, miR-155 and miR-223 expression from PBMCs could be diagnostic in discriminating knee OA from RA. Additional examination found that the expression of miR-155 was found to be significantly up-regulated in late-stage radiographic OA when compared to earlier radiographic stages of OA, whereas, expression of miR-146a and miR-223 were found to be significantly up-regulated in early-stage radiographic OA compared to late-stage radiographic OA [74]. Combined assessment of miR-146a, miR-155 and miR-223 expression levels from PBMCs could serve as diagnostic indicators of disease progression.

\subsubsection{Long non-coding RNA (IncRNA)}

Due to their diverse structures and functions the definition of lncRNAs is limited to ncRNAs of more than 200 nucleotides in length which lack protein coding capability [75]. Attempts have been made to classify lncRNAs by means of their relationship to coding genes, genomic origin and level of processing [76]. For example, IncRNAs have been classified according to molecular mechanism and can be subtyped as having signalling, decoy, guide, scaffold and enhancer roles [77]. LncRNAs can also be subtyped according to their position and direction of transcription relative to other genes and can be classified into subtypes including intergenic, intronic, antisense, overlapping, processed and bidirectional lncRNAs [78].

Zhang et al observed the expression of the lncRNA HOTAIR to be significantly up-regulated in the synovial fluid of the temporomandibular joint (TMJ) of OA patients and also in the synovial fluid of mechanical-stress-induced OA TMJ in rabbits. The authors demonstrated that treatment of rabbit TMJ 
condylar chondrocytes with IL-1 $\beta$ induced the up-regulation of HOTAIR and knockdown of HOTAIR resulted in down-regulation of both mRNA and protein levels of Mmp1, Mmp3 and Mmp9 and a decrease in IL-1 $\beta$ induced apoptosis, indicating that the lncRNA HOTAIR may play a role in chondrocyte apoptosis in OA [79]. Synovial fluid HOTAIR from TMJs could potentially function as a biomarker of OA of the TMJ joint.

The knowledge surrounding extracellular lncRNA expression in OA is limited, but studies of lncRNA expression in cells of the OA joint have been documented. Expression of lncRNAs in OA cartilage tissue and/or chondrocytes and synoviocytes, such as PCGEM1, GAS5, HOTTIP, LncRNA-CIR, H19, CILinc01 and CILinc02 have been observed, with roles in apoptosis, ECM degradation and inflammation [80]. Various studies have demonstrated expression of circulating lncRNAs in body fluids of cancer patients including in whole blood, urine, plasma, saliva and gastric juice [46] and circulating IncRNAs have been identified in endometriosis [81], acute myocardial infarction [82] and rheumatoid arthritis [83]. The field of lncRNA research is relatively young but holds promise for novel potential prognostic biomarkers for diseases including OA. It is likely that other extracellular lncRNAs involved in $\mathrm{OA}$ are yet to be identified.

\subsubsection{Small Nucleolar RNA (snoRNA)}

SnoRNAs, a sub-class of snRNA located in the nucleus, are involved with post-transcriptional modification by means of methylation or pseudouridylation of ncRNA including snRNA, rRNA and tRNA. SnoRNAs are divided into two classes, SNORDs and SNORAs, dependent on their structural features and sequences [84]. SnoRNAs are involved in rRNA processing, which is fundamental for ribosome biogenesis and ultimately translation and protein synthesis. Dysregulation of snoRNA is likely to have an impact on protein synthesis. Dysregulation of snoRNAs has been observed in certain cancers, neurodegenerative disease and viral induced diseases and changes in snoRNA levels have been observed in cells subjected to stress and drugs [85]. Differential expression of specific snoRNAs has also been observed in patients with cartilage damage associated with post-anterior cruciate ligament (ACL) damage [86] and in OA [87].

Zhang et al investigated the presence of ncRNA in the serum of patients with cartilage damage one year after patients had undergone arthroscopic ACL reconstruction surgery following ACL injury. The study looked to identify potential ncRNAs involved in early degenerative changes which may be associated with post-ACL injury-induced OA. At one year post-ACL injury, the concentration of U48 and U38 were significantly elevated in the serum of patients developing cartilage damage. The concentration of U38 was also found to be significantly elevated in cartilage with greater damage, assessed by whole organ magnetic resonance knee score, compared to cartilage with minor damage. Not only could both U48 and U38 from serum serve as biomarkers of cartilage damage which may lead to OA, but assessment of U38 concentration could be utilised to discriminate between stages of cartilage damage 
[86]. If U38 concentration is correlated with increasing cartilage damage it may be a good indicator for early-onset injury-induced OA, further examination of U38 in early radiographic OA would be insightful.

In an in vivo experimental induced OA murine model, the expression of SNORD116, SNORA64 and U3 were found to be significantly up-regulated and the expression of SNORD46 was found to be significantly down-regulated in mice serum. The up-regulated expression of SNORD116 was also confirmed in another species, with a significant up-regulation in SNORD116 observed in OA equine serum [87]. SNORA64, U3, SNORD46 and SNORD116 could serve as biomarkers of OA and future examination of the expression of these snoRNAs in human OA serum is required.

\subsection{Cell-Free, Carrier-Free Nucleic Acids}

Cell-free nucleic acids encompass DNA and RNA which are not associated with cells, freely circulating in the blood and other body fluids [88]. Apoptosis or necrosis has been speculated to be the main source of cfDNA and RNA in plasma and serum [89,90]. CfDNA is not carrier-associated, while cell-free RNA is likely to be associated with a carrier [40]. Extracellular cfDNA is double stranded and short in length due to fragmentation, with most DNA molecules measuring approximately $170 \mathrm{bp}$ in length, resemblant of the smallest nucleosomal DNA fragment resultant of apoptosis [91]. Elevated cfDNA has been observed in various human diseases including myocardial infarction [92], acute pancreatitis [93], rheumatoid arthritis, systemic lupus erythematosus [94] and various types of cancer [95].

Leon et al examined the levels of extracellular DNA from patients with RA, OA, gout, pseudogout and post-traumatic arthritis (TRA) and identified that the concentration of DNA from both synovial fluid and serum was significantly higher in patients with RA compared to OA [96]. Hashimoto et al observed a significant increase in the concentration of cfDNA in the synovial fluid of RA patients compared to the concentration in OA patients [97]. Extracellular cfDNA may therefore serve as a biomarker to distinguish OA from RA. While DNA levels have been compared in RA and OA, no study has examined the levels of cfDNA in progressive radiographic OA. In late-stage OA chondrocyte apoptosis is evidenced by hypocellularity and lacunae emptying [98]. Given the association of increased cfDNA with elevated apoptosis or necrosis [99], an elevated level of cfDNA may be detected in late-stage radiographic OA compared to an earlier stage of radiographic OA.

\subsection{Peripheral blood mononuclear cells (PBMCs) as a source of genomic biomarkers}

Circulating blood contains PBMCs which encompass lymphocytes, natural killer cells, dendritic cells, monocytes [100] and a small percentage of haematopoietic stem and progenitor cells [101]. PBMCs are resident in an easily attainable fraction of blood, comprised of cells which actively undergo transcription and translation. The circulating mononuclear cells undergo immunophenotypic changes in response to disease and injury and therefore provide a peripheral source [102] for assessing gene and ncRNA expression relevant to different diseases. Chronic low-grade inflammation is a major driver of continual 
degeneration of joint tissues in OA [103]. Infiltration of subsets of PBMCs including $\mathrm{T}$ and $\mathrm{B}$ lymphocytes, natural killer cells and macrophages into the synovium [103,104] and alterations in blood immune cell composition has been observed in OA [105]. Gene expression profiling of PBMCs offers a minimally invasive technique for potentially identifying novel biomarkers for OA.

Several studies have identified specific gene expression profiles of PBMCs in OA, which could serve as novel genomic biomarkers of the disease. As discussed previously, the significant up-regulation of miR-146a, miR-155, miR-181a and miR-223 was observed in PBMCs isolated from patients with knee OA [74]. RNA expression profiling of RNA isolated from the blood of patients with arthroscopically diagnosed mild knee OA revealed 3,543 genes to be differentially expressed. Significant downregulation of HSPCA, IKBKAP, IL13RA1, LAMC1, TNFAIP6 and PF4 mRNA following qPCR validation was observed in patients with mild knee OA compared to controls [106]. Marshall et al suggest that utilising a combination of specific mRNA expression analysis of blood-derived RNA provides a more sensitive and non-invasive method to diagnose mild knee OA [106]. Ramos et al observed the differential expression of 679 protein coding genes and 15 ncRNAs in PBMCs from a cohort of patients with symptomatic OA in multiple joints in the hand or at least two joints from hand, spine, knee or hip. Differential expression of 22 genes identified out of the 694 were observed to be differentially expressed following qPCR validation and also in an independent cohort of OA patients [107].

Attur et al identified 173 differentially expressed genes in PBMCs from patients with OA and also showed that symptomatic knee OA patients could be categorised into two subclasses dependent on the expression of cytokines in PBMCs. Individuals that exhibited up-regulated expression of cytokines in PBMCs, sub-classed as cytokine overexpressors, were found to have higher pain scores and a higher risk for symptomatic radiographic knee OA progression. Cytokine gene expression profiling of PBMCs may therefore identify a subset of patients with an inflammatory phenotype who may be at risk of rapid OA progression [108].

An in vivo murine model of monosodium iodoacetate-induced OA enabled examination of whole blood gene expression profiles with the development of OA, identifying time-dependent differential gene expression and therefore potential stage-specific genomic biomarkers of OA progression. Additionally, utilising the gene expression dataset from the study conducted by Ramos et al [107], common differential gene expression changes in both OA patients and the murine model dataset were examined. The expression of TNK2, WDR37 and KCTD2 mRNA were found to be differentially expressed in both studies [109].

In addition to measurements of RNA as a source from PBMCs as potential OA genomic biomarkers, measurements of DNA or DNA characteristics from PBMCs may also function as genomic biomarkers of OA. PBMC DNA methylation examination identified differential methylation of $44 \mathrm{CpG}$ sites 
between PBMC DNA obtained from OA patients with rapid-progressive radiographic knee OA and PBMC DNA from patients with non-progressive radiographic knee OA. Differential DNA methylation may therefore serve as a genomic biomarker for predicting rate of OA radiographic progression in symptomatic knee OA patients [110].

Despite the relatively low number of studies conducted to date which examine extracellular genomic material in OA, some of the studies identify the same genomic marker in individuals with knee OA. The expression of miR-146a was found to be dysregulated in studies of the synovial fluid [67,68], as well as plasma [72] and PBMCs [74], indicating that miR-146a may be a favourable extracellular genomic biomarker for identifying individuals with knee OA. The observed expression of miR-146a in differing body fluids of individuals with knee OA indicates the usage of several body fluids for examining the levels of miR-146a in the potential diagnosis of knee OA. The studies outlined demonstrate the recent efforts to identify soluble extracellular genomic biomarkers of OA. Larger cohorts are required to examine and validate these potential extracellular genomic biomarkers of OA.

\subsection{Liquid biopsies - the potential for genomic biomarkers of $\mathrm{OA}$ in diagnostic testing}

Liquid biopsy is a non-invasive tool for analysing different components of biological fluids to make a diagnosis without the need of invasive techniques [111]. Components of body fluids such as cfDNA, RNA subtypes including mRNA, miRNA and lncRNA, proteins, exosomes, cfDNA characteristics including methylation, integrity, mutation and copy number can be measured following liquid biopsy [112]. Liquid biopsy provides a non-invasive approach which is associated with decreased morbidity and can be performed successively offering temporal disease monitoring [112]. In 2015 liquid biopsy was listed as a top ten technology breakthrough by the MIT Technology Review [113]. Liquid biopsies are already used in the clinicand some of the diagnostic tests which currently employ liquid biopsies for measuring extracellular genomic material are outlined below.

Exosome Diagnostics produced the first blood-based liquid biopsy cancer diagnostic, ExoDx Lung $(A L K)$, which measures exosomal-derived EML4-ALK fusion transcripts from the plasma of patients with non-small cell lung cancer [114]. Exosome Diagnostics also produced the first urine-based liquid biopsy diagnostic, ExoDx Prostate (IntelliScore), which detects exosomal-derived RNA of ERG, PCA3 and $S P D E F$ in the urine of men with prostate-specific antigen, to discriminate high grade from lowgrade prostate cancer and benign disease [115]. The AlloMap test, marketed by CareDx, is a noninvasive blood test to analyse RNA from PBMCs for the expression of 20 genes, to assess the risk of moderate/severe acute cellular rejection in cardiac transplant recipients [116]. Recently CareDx has brought to market another non-invasive blood test, AlloSure, which measures donor-derived cfDNA to determine active rejection of kidney allografts in renal transplant recipients [117]. All of the genomic liquid biopsy based diagnostic assays outlined above offer non-invasive screening over previously available invasive procedures. Measurement of extracellular genomic material and measurements of 
characteristics of genomic material from body fluids including synovial fluid and blood provides a promising method for the identification of genomic biomarkers of early-onset OA and in monitoring OA disease progression. Ultimately liquid biopsies such as synovial fluid and blood sampling could be used in the diagnosis and monitoring of OA disease progression in the future.

\section{Extracellular carriers of genomic material as potential indicators of $\mathrm{OA}$ disease progression}

Stability of extracellular RNA is likely to be attributable to association of RNA with extracellular carriers such as exosomes, microvesicles, apoptotic bodies, lipoproteins or protein complexes [39]. EVs can be categorised into exosomes, microvesicles and apoptotic bodies and are generated through distinct cellular mechanisms. Exosomes refer to EVs that are of endosomal origin. Endosomes constitute part of the network which guides cell contents to either lysosomes for lysosomal degradation or the cell surface membrane for secretion. Fusion of intracellular multivesicular bodies, which constitute the endosomal pathway, with the plasma membrane results in secretion of exosomes into the extracellular space [118]. Microvesicles are of plasma membrane origin and are formed through the budding and fission of the plasma membrane [118]. Apoptotic bodies are only formed during apoptosis. Cells undergoing programmed cell death follow a process of nuclear chromatin condensation, followed by membrane blebbing and the dissolution of the cell contents into membrane enclosed vesicles, known as apoptotic bodies [118].

In addition to EVs as carriers of extracellular RNA are lipoproteins and protein complexes. Lipoproteins are an assembly of phospholipids, apolipoproteins, cholesterol and a core containing triglycerides and cholesterol esters [119]. Human high density lipoproteins (HDLs) have been shown to contain small RNAs and have been suggested to function in intercellular communication through transportation of miRNA [120]. Extracellular miRNA has also been shown to be associated with argonaute proteins [66,121] and miRNA association with argonaute proteins increases miRNA stability [122]. During intracellular miRNA mediated mRNA targeting, mature miRNAs complex with argonaute proteins to form a ribonucleoprotein complex, the RNA-induced silencing complex (RISC) [123], therefore miRNA association with argonaute proteins in the extracellular environment is not unexpected.

With regards to using extracellular genomic material as potential soluble genomic biomarkers of OA, the associated nucleic acid carrier and therefore the pathway of secretion of genomic material from any of the affected cells of the joint into extracellular environments may be extremely relevant to identifying specific stage-related OA genomic biomarkers. The extent to which intracellular nucleic acids are released from cells non-selectively and the extent to which intracellular nucleic acids are predetermined and sorted for extracellular secretion in a paracrine manner is unknown [124]. Two hypotheses have been proposed for the existence of extracellular miRNA: the existence of selective miRNA export systems have been proposed and alternatively the concept that extracellular miRNA are 
merely by-products of cell activity and cell death [125] and therefore released non-selectively. But it is likely that intracellular RNA can be released both selectively and non-selectively.

Following cell death, tissue-specific RNAs may be released non-selectively, whereby the elevated expression of extracellular RNA may reflect the high abundance of RNA that were located in the cells of origin. While RNA release may be as a consequence of leakage from damaged cells undergoing apoptosis and/or necrosis, RNA release may also have a biological function, in which case RNA may be selectively released utilising specific intracellular membrane trafficking pathways. Approximately $90 \%$ of circulating miRNAs have been suggested to be associated with a ribonucleoprotein complex, while approximately $10 \%$ have been suggested to be vesicle-associated [121]. Turchinovich et al proposed that the majority of circulating miRNA that are bound to the ribonucleoprotein Ago2, are likely to be by-products of dead cells [66]. In late-stage OA, chondrocyte apoptosis is evidenced by hypocellularity and lacunae emptying [98]. If the majority of circulating miRNA that are bound to Ago2 are likely to be by-products of dead cells [66], measurements of only non-vesicle Ago2-associated miRNAs in the extracellular fluids of OA patients could serve as potential biomarkers for apoptosis of specific joint cells and therefore give a potential indication of disease progression.

\section{Future challenges for genomic biomarkers of osteoarthritis}

A biomarker can be defined as anything which enables an observation of medical state to be made from outside of the patient, which can be measured both accurately and reproducibly [126], a defined characteristic which when measured gives an indication of normal biological processes, pathogenic processes and responses to an intervention or exposure. Recent efforts have identified that extracellular nucleic acids, both carrier-associated and non-carrier associated, including miRNA, IncRNA, snoRNA and DNA have been identified to exhibit differential expression in extracellular environments in OA and could therefore serve as appropriate soluble genomic biomarkers of OA. Future studies to examine these identified potential genomic biomarkers for reproducibility in larger validation cohorts are required.

While efforts are required to advance the identification of biomarkers in OA, efforts will also be required to identify individuals at-risk of developing OA through the implementation of screening programmes as routine procedure in clinical practice. A limitation of soluble biomarker discovery is the asymptomatic nature of pre-OA which limits the point in time at which an individual can be directed for examination. Chu et al suggest that longitudinal studies of human joint-injured cohorts provide the opportunity to characterise and define pre-OA because these populations have joint pathologies whereby OA is likely to develop [127]. With regards to identifying a genomic biomarker for pre-OA, one idea could be the implementation of a longitudinal study with use of extracellular nucleic acid profiling in individuals who have been subject to a joint injury. For example, as discussed previously, Zhang et al identified extracellular ncRNAs one year after ACL injury and examined the correlation of 
serum-derived ncRNA concentration with extent of cartilage damage [86]. Studies need to focus on identification and stratification of at-risk asymptomatic individuals without radiographic OA for longitudinal studies with cohorts which are likely to have a predisposition of developing a specific phenotype of OA.

An injury driven phenotype is just one subtype of OA. Given the complex nature of OA, it is likely that no single biomarker will be appropriate for all phenotypes of OA. In addition to the differing phenotypes of OA is also the anatomical location of OA. At present, OA can be categorised into primary (idiopathic) $\mathrm{OA}$ and secondary OA. Secondary OA is associated with causes such as congenital or developmental deformities, preceded joint trauma or surgery, metabolic or endocrine disorders. Primary OA is most common and occurs in joints with no prior damage and can be further categorised into generalised and localised OA. Generalised OA (polyarticular) occurs in multiple joints, whereas localised OA is confined to 1 or 2 joints [128]. Most extracellular genomic material studies of OA to date, discussed in this review, examine the expression of extracellular genomic material in patients with only knee OA. While knee OA genomic biomarker discovery will be more accelerated, genomic biomarker discovery of OA of the hip, OA of the joints of the hand and generalised OA may lag behind. Future priorities need to categorise OA into disease subtypes according to potential underlying phenotype in addition to anatomical location/s, with the view to identify soluble biomarkers that are inherent to a specific type of OA.

Of the extracellular genomic material studies of OA to date, discussed in this review, only one study isolated RNA from the exosome fraction of synovial fluid [68], all of the other studies isolated total RNA from either synovial fluid, serum or plasma. The method of RNA isolation from extracellular fluid is likely to be relevant to identifying genomic biomarkers, with potential differences in extracellular RNA expression dependent on the isolation procedure utilised. However, at present, limitations exist in the lack of discrimination between extracellular nucleic acid carriers. Isolation of a pure EV fraction from extracellular fluids is challenging because non-vesicular entities such as lipoproteins and proteins complexes are not separated from EVs by isolation protocols such as centrifugation [129] and Ago-2 has been identified inside exosomes [130]. Furthermore there is much overlap in the sizes of specific EVs, with exosomes measuring between $40-200 \mathrm{~nm}$ in diameter, microvesicles measuring between 50 $1000 \mathrm{~nm}$ in diameter and apoptotic bodies measuring between 500-2000 nm in diameter [131] which makes separation and isolation of subtypes of EVs difficult. Lack of defined nucleic acid carrier isolation and characterisation techniques may limit efforts to examine selective and non-selective release of nucleic acid from chondrocytes and synoviocytes. What is critical in extracellular genomic biomarker research is the necessity to appropriately document extracellular sources of genomic material with the implementation of strict guidelines for categorising nucleic acid carriers.

Personalised medicine is a rapidly growing field which is informed by the underlying molecular mechanisms of a disease in order of optimising preventative health care strategies, directing medical 
care towards assessing disease risk and prevention [132]. A companion diagnostic is any in vitro diagnostic device or imaging tool that provides essential information for the safe and effective use of a corresponding therapeutic product [133]. The importance of identifying a soluble biomarker/s of OA, is the potential that biomarker may have in being utilised as a liquid biopsy-based companion diagnostic for screening participants in the detection of OA for inclusion in clinical trials, in the development of much needed DMOADSs [134].

\section{Expert commentary}

The definitive objective of OA biomarker research is to identify OA prior to radiographic evidence of OA. For the future, an annual biological test is necessary to detect pre- or early-onset OA while OA is either still curable or at a less advanced stage of the disease progress at which point potential DMOADs will forestall the progression of the disease. All cells release nucleic acids into the extracellular environment and by association with RNA-binding proteins or lipoproteins or carriage within EVs, nucleic acids are thought to be protected from degradation. Biological fluids are more accessible than tissues and provide an appealing and non-invasive source for the measurement of extracellular genomic material. Future OA research prerequisites include identifying stable and reproducible extracellular genomic biomarkers of pre- and early-onset $\mathrm{OA}$ and extracellular genomic biomarkers which can discriminate between stages of OA progression, which may lead to the creation of OA specific noninvasive liquid biopsy diagnostics.

Documented to date, genomic material that has been observed in extracellular environments in OA, such as synovial fluid and plasma and/or serum includes cfDNA, miRNA, lncRNA and snoRNA. A diverse composition of RNA subsets have been identified in EVs including tRNA fragments, rRNA, vault RNA, circRNA, piRNA, Y RNA (Table 2) [36] and cell-free telomeric repeats-containing RNA (cfTERRA) [135], all of which could be present and exhibit differential expression in the extracellular fluids of OA patients. Future studies to investigate the presence of RNA subsets in OA may reveal additional RNA candidates that could serve as genomic biomarkers of OA. Other epigenomic alterations such as histone modifications [136], enabling measurements of histone methylation, acetylation, phosphorylation and ubiquitination in PBMCs of OA patients, may also function as potential genomic biomarkers. Extracellular fluid analysis holds much promise for the identification of genomic biomarkers of OA, but a combination of techniques inclusive of genomics, proteomics, and metabolomics used together, is likely to identify a more powerful biomarker panel capable of detecting OA early.

Recently liquid biopsy has gained much attention in the cancer sciences field, but this novel technique set to revolutionise diagnostics has far reaching implications not just in the field of oncology but in other diseases too. As advances are made in OA research, in the future not only could liquid biopsy be a useful method for OA disease progression monitoring, but also in the initial screening of individuals 
for OA detection and also in the stratification of individuals according to OA phenotype, made possible by anticipated discovery of reliable informative single nucleotide polymorphisms.

Beyond the scope of this review is the potential link that mechanisms of selective and non-selective release of genomic material from cells of the OA joint may have in OA disease pathogenesis. In the search for a suitable extracellular biomarker of OA opens up questions about the potential role that conventional and unconventional secretory pathways may have in secreting genomic material to the extracellular environment. In addition to exploring intracellular trafficking pathways including exocytosis, microvesical shedding and exosome secretion, exploring exosome secretion as a result of plasma membrane fusion with secretory lysosomes and amphisomes in addition to multivesicular bodies may reveal links to autophagy and an indication of underlying cellular health in OA. The extent of which specific nucleic acid carrier subtypes are released from cells of the joint may have indications for cellular homeostatic status. The type of extracellular carrier associated with extracellular genomic material and the mode of secretion may indicate how cells of the joint function in health and disease, revealing roles for genomic material in cell-cell communication and the potential to reveal more about the underlying pathophysiology of OA. A more profound understanding of the mechanisms of release of genomic material into the extracellular environment in the cells of the joint is required.

\section{Five-year view}

At present, the field of extracellular genomic biomarker research is primitive and in the next few years, extracellular genomic biomarker research is anticipated to grow, with the identification of novel subsets of extracellular RNA isolated from the extracellular fluids of OA patients. In vitro cell and explant culture systems will likely be routinely used to validate and further explore identified extracellular genomic biomarkers. It is expected that there will be a focus on EV-derived genomic material and it is anticipated that technologies utilised to extract extracellular genomic material will continue to grow and move towards isolation of pure fractions of extracellular nucleic acid carrier subtypes, such as subsets of EVs. As a greater understanding regarding extracellular genomic material develops, pathways of intracellular cell trafficking of genomic material to the plasma membrane will also develop and may reveal more about the underlying dysregulated mechanisms which may be involved in the pathophysiology of OA. In addition to expected identification of extracellular metabolomic and proteomic biomarkers of $\mathrm{OA}$, with the identification of differential measurements of extracellular genomic material in $\mathrm{OA}$ which could function as genomic biomarkers of OA, the number of human biomarker studies to assess panels of a combination of biomarkers from different body fluids is expected to increase. It is anticipated that in the event of successful identification of soluble biomarkers for diagnosing OA, soluble biomarkers will be in the first instance adjunct to and then definitively in place of radiographic measurements as the regulatory endpoint in DMOAD development.

\section{Key Issues}


- Osteoarthritis (OA) is a chronic and debilitating disease which affects approximately a third of the UK's population that are aged over 45 years and a diagnosis of OA is currently based on radiographic findings at which point structural changes are observed in the affected joint.

- While recent efforts have looked to address the notion that OA is indeed a serious disease, much more needs to be done to drive forwards biomarker discovery and the development of DMOADs.

- The OA disease process is estimated to begin 20 years prior to detection by radiographic joint space narrowing with the likelihood that molecular indicators exist at the cellular level only, a stage that can be defined as pre-OA.

- No soluble biomarkers exist which can detect OA or determine the progression of the disease. Asymptomatic OA is a common phenomenon. Identification of suitable soluble biomarkers would potentially help identify asymptomatic individuals and also pre-OA in routine screening and to assess disease progression.

- Examination of extracellular body fluids for biomarkers offers a non-invasive method for assessing disease state. Body fluids including synovial fluid and blood which can be analysed for measurements of extracellular genomic material have the potential to serve as liquid biopsies in the diagnosis of OA.

- Several recent studies observe the differential expression of subsets of ncRNA in extracellular fluids including synovial fluid, plasma and serum of OA patients, indicating the potential use of ncRNAs such as miRNAs, IncRNAs and snoRNAs as diagnostic and prognostic biomarkers for OA.

- Studies of PBMCs in OA has observed the differential expression of miRNA, mRNA and differential measurements of DNA methylation, suggesting that isolation of PBMCs could provide a source of genomic material as diagnostic and prognostic biomarkers for assessing OA disease.

- RNA exists in extracellular fluids by association with a carrier, which protects the RNA from degradation. Carriers of genomic material may include lipoproteins, protein carriers and EVs such as exosomes, microvesicles and apoptotic bodies.

- The type of carrier that genomic material may be associated with may give indications about how intracellular genomic material is secreted or released to the extracellular environment. How genetic material is secreted or released from cells of the joint including chondrocytes and synoviocytes, with regards to specific intracellular trafficking pathways, may give an indication to the underlying health of the cell of origin and reveal more about OA pathophysiology.

- Drug and biomarker development are interdependent. The development of DMOADs requires a biomarker which can detect $\mathrm{OA}$ and predict $\mathrm{OA}$ disease progression. In the future, 
identification of OA before radiographic evidence of OA, using extracellular-derived soluble biomarkers, could see the use of effective DMOADs forestalling the onset of OA. 


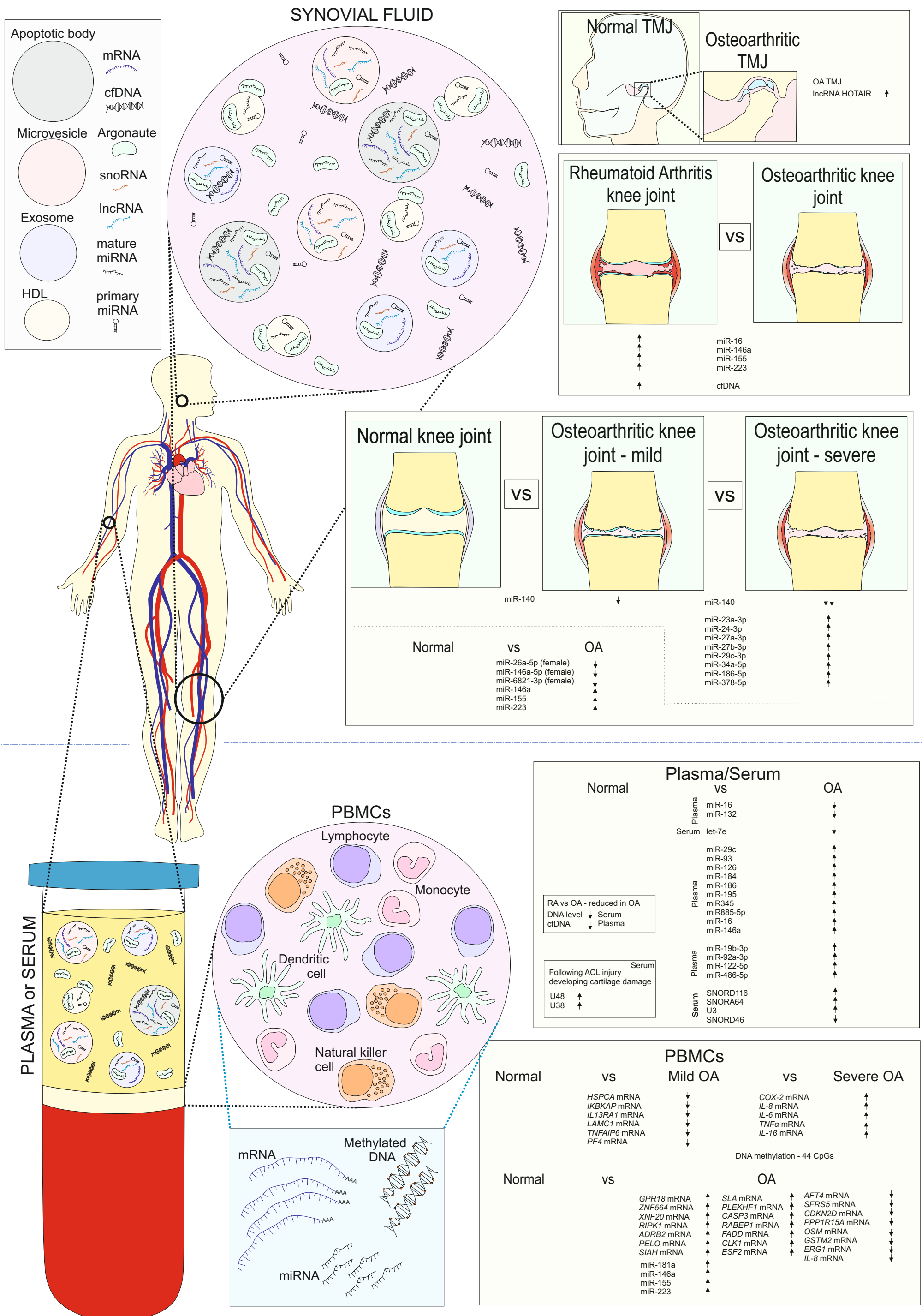


Figure 1. Extracellular carrier-associated and extracellular carrier-free genomic material from body fluids with the potential to serve as genomic biomarkers in OA. To date extracellular genomic material has been identified in synovial fluid, plasma and serum. Peripheral blood mononuclear cells (PBMCs) have been isolated from blood and identified to exhibit differential expression of mRNA and miRNA in OA patients. PBMCs include monocytes, lymphocytes, dendritic cells and natural killer cells. Extracellular genomic material found in synovial fluid, plasma and/or serum may be contained inside extracellular vesicles including apoptotic bodies, microvesicles and exosomes or associated with a protein complex such as Argonaute2 or high density lipoproteins (HDLs) or not associated with a carrier, such as cell-free DNA (cfDNA). TMJ -Temporomandibular joint. $\uparrow$ - Up-regulated expression or concentration. $\downarrow$ - Down-regulated expression or concentration. Documented studies have observed the differential expression/concentration/level of specific extracellular genomic material between rheumatoid arthritis patients (RA) and patients with knee OA, between non-OA patients and patients with mild and severe knee OA, between non-OA patients and mild OA patients, between non-OA patients and patients with TMJ OA. 

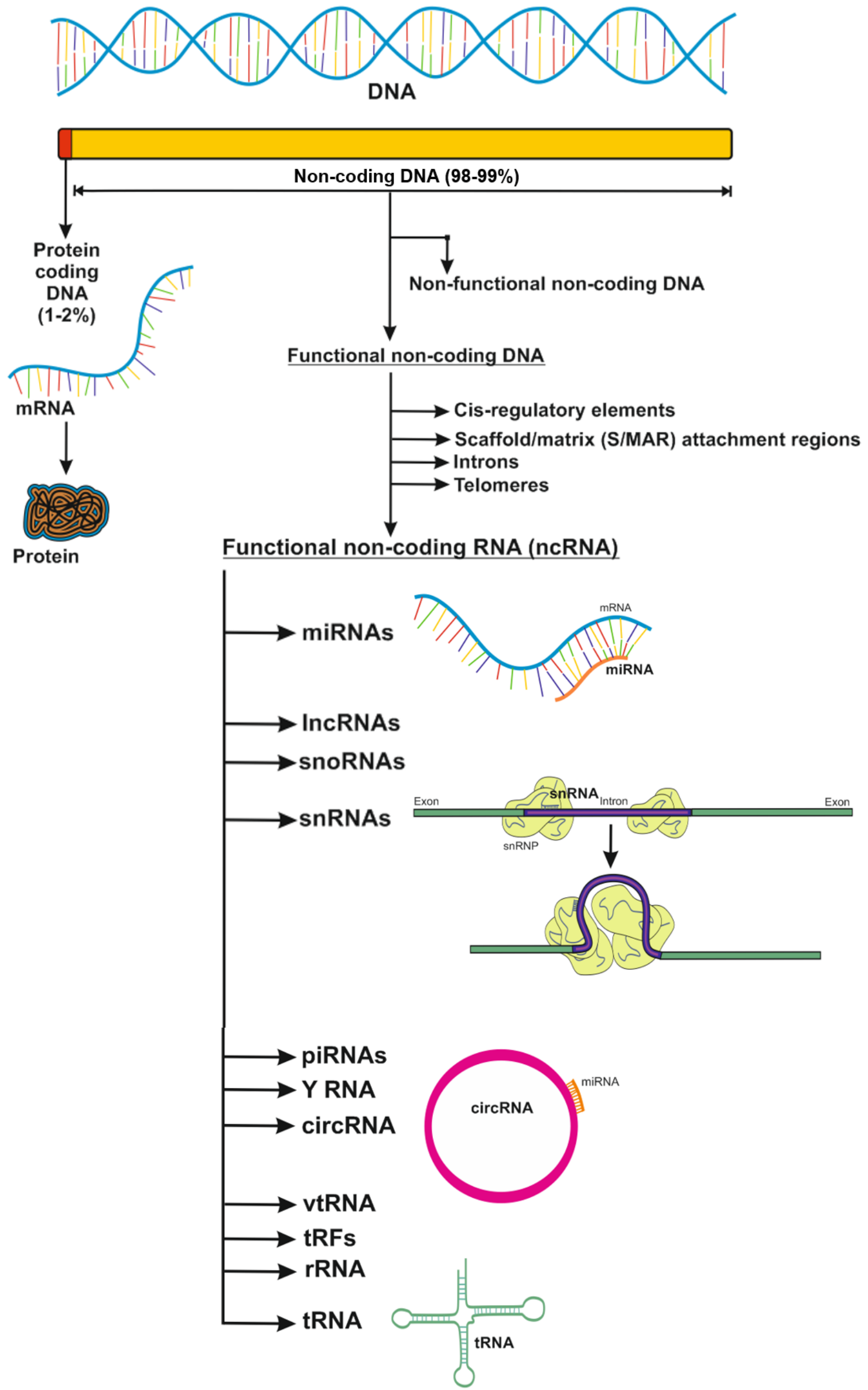
Figure 2. DNA encodes both protein coding genes and non-coding DNA. Only a small proportion of DNA is protein coding DNA, in which the DNA is transcribed to mRNA which in turn is translated to protein. Non-coding DNA includes non-functional DNA which has no known function and functional DNA which includes DNA sequences which have known functions and include for example: cis-regulatory elements, scaffold/matrix (S/MAR) attachment regions, introns, telomeres and DNA which encodes genes for non-coding RNA. Functional non-coding RNA encompasses RNAs which are not translated into protein but have functional roles and include miRNAs, IncRNAs, snoRNAs, snRNAs, piRNAs, vtRNAs, Y RNA, circRNAs, tRFs, rRNAs and tRNAs. Many ncRNAs have housekeeping and regulatory roles. SnRNAs for example have roles in processing pre-mRNA during splicing and tRNA is fundamental to protein biosynthesis in ribosomes. MiRNAs have roles in regulating gene expression, via post-transcriptional regulation of mRNA, generally via binding to the 3'UTR of target mRNA. One function of circRNA is the regulation of gene expression through the targeting of miRNA, enabling derepression of miRNA targeted mRNA. 


\begin{tabular}{|c|c|c|c|c|c|c|c|}
\hline $\begin{array}{c}\text { Extracellular } \\
\text { Fluid }\end{array}$ & $\begin{array}{c}\text { Anatomical } \\
\text { location of } \\
\text { OA }\end{array}$ & $\begin{array}{c}\text { Genomic } \\
\text { material } \\
\text { source }\end{array}$ & OA Study & \begin{tabular}{|c|} 
Extracellular \\
genomic \\
material \\
expression \\
profiling \\
results \\
\end{tabular} & $\begin{array}{c}\frac{\text { Extracellular genomic }}{\text { material }} \\
\text { expression/level/concen } \\
\text { tration following } \\
\text { validation }\end{array}$ & $\begin{array}{c}\text { Potential } \\
\text { indication } \\
\text { for genomic } \\
\text { material }\end{array}$ & Ref. \\
\hline \multicolumn{8}{|c|}{ MicroRNA } \\
\hline $\begin{array}{l}\text { Human } \\
\text { synovial Fluid }\end{array}$ & Knee & $\begin{array}{l}\text { Total RNA } \\
\text { from } \\
\text { synovial } \\
\text { fluid. }\end{array}$ & $\begin{array}{l}\text { Differential expression of } \\
\text { synovial fluid miRNAs } \\
\text { between radiographic } \\
\text { early-stage and late-stage } \\
\text { OA (assessed by KL } \\
\text { grading). }\end{array}$ & $\mid \begin{array}{l}14 \quad \text { miRNAs } \\
\text { differentially } \\
\text { expressed in } \\
\text { miRNA PCR } \\
\text { array. }\end{array}$ & \begin{tabular}{|c|} 
miR-23a-3p $\uparrow$ \\
miR-24-3p $\uparrow$ \\
miR-27a-3p $\uparrow$ \\
miR-27b-3p $\uparrow$ \\
miR-29c-3p $\uparrow$ \\
miR-34a-5p $\uparrow$ \\
miR-186-5p $\uparrow$ \\
miR-378a-5p $\uparrow$ \\
(Significantly up- \\
regulated in late-stage \\
OA compared to early- \\
stage OA). \\
\end{tabular} & $\begin{array}{l}\text { Prognostic } \\
\text { biomarkers } \\
\text { of knee OA } \\
\text { disease } \\
\text { progression. }\end{array}$ & {$[69]$} \\
\hline \begin{tabular}{|ll|}
\multicolumn{2}{|l|}{ Conditioned } \\
media & from \\
human & \\
synovial & \\
explant culture \\
\end{tabular} & $\begin{array}{l}\text { Synovial } \\
\text { explants } \\
\text { from the } \\
\text { knee joint }\end{array}$ & $\begin{array}{l}\text { Total RNA } \\
\text { from cell } \\
\text { culture } \\
\text { supernatant. }\end{array}$ & $\begin{array}{l}\text { Differential expression of } \\
\text { cell culture supernatant } \\
\text { miRNAs in response to IL- } \\
1 \beta \text { stimulation. }\end{array}$ & - & \begin{tabular}{|c|} 
miR-23a-3p $\uparrow$ \\
miR-27b-3p $\uparrow$ \\
(Significantly \\
upregulated with IL-1 \\
stimulation). \\
\end{tabular} & \begin{tabular}{|l|} 
Diagnostic \\
biomarkers \\
of \\
inflammator \\
y knee OA.
\end{tabular} & [69] \\
\hline $\begin{array}{l}\text { Human } \\
\text { synovial Fluid }\end{array}$ & Knee & $\begin{array}{l}\text { Total RNA } \\
\text { from } \\
\text { synovial } \\
\text { fluid. }\end{array}$ & $\begin{array}{l}\text { Differential concentration } \\
\text { of synovial fluid miRNAs } \\
\text { between patients with OA } \\
\text { and RA } \\
\text { (assessed by } 1986 \\
\text { classification of knee OA } \\
\text { in diagnostic criteria of the } \\
\text { American Rheumatism } \\
\text { Association [137]). }\end{array}$ & - & \begin{tabular}{|c} 
miR-16 $\downarrow$ \\
miR-146a $\downarrow$ \\
miR-155 $\downarrow$ \\
miR-223 $\downarrow$ \\
(Lower concentration in \\
OA compared to RA)
\end{tabular} & $\begin{array}{l}\text { Diagnostic } \\
\text { biomarkers } \\
\text { of knee OA } \\
\text { and RA. } \\
\text { Assessment } \\
\text { of } \\
\text { concentratio } \\
\text { n required to } \\
\text { differentiate } \\
\text { knee OA } \\
\text { from RA - } \\
\text { lower } \\
\text { concentratio } \\
\text { n in OA than } \\
\text { RA. }\end{array}$ & {$[67]$} \\
\hline $\begin{array}{l}\text { Human } \\
\text { plasma }\end{array}$ & Knee & $\begin{array}{l}\text { Total RNA } \\
\text { from plasma }\end{array}$ & $\begin{array}{l}\text { Differential expression of } \\
\text { plasma miRNAs between } \\
\text { patients with OA, RA and } \\
\text { healthy controls (HC) } \\
\text { (assessed by } 1986 \\
\text { classification of knee OA } \\
\text { in diagnostic criteria of the } \\
\text { American Rheumatism } \\
\text { Association [137]). }\end{array}$ & - & $\begin{array}{c}\text { miR-16 } \downarrow \\
\text { miR-132 } \downarrow \\
\text { (Significantly lower } \\
\text { concentration in OA } \\
\text { compared to HC) }\end{array}$ & $\begin{array}{l}\text { miR-132 } \\
\text { diagnostic } \\
\text { biomarker of } \\
\text { knee OA and } \\
\text { RA, but not } \\
\text { inherent to } \\
\text { knee OA as } \\
\text { no } \\
\text { differences } \\
\text { observed } \\
\text { when OA } \\
\text { compared to } \\
\text { RA. } \\
\text { miR-16 - } \\
\text { diagnostic } \\
\text { biomarker of } \\
\text { knee OA. }\end{array}$ & {$[67]$} \\
\hline $\begin{array}{l}\text { Human } \\
\text { synovial Fluid }\end{array}$ & Knee & $\begin{array}{l}\text { Total } \\
\text { miRNA } \\
\text { from }\end{array}$ & \begin{tabular}{|lr} 
Differential & expression of \\
synovial & fluid-derived \\
extracellular & vesicle- \\
derived miRNAs & between \\
\end{tabular} & $\begin{array}{l}114 \text { miRNAs } \\
\text { differentially } \\
\text { expressed in } \\
\text { males }\end{array}$ & $\begin{array}{r}\operatorname{miR}-26 a-5 p \\
\text { miR-146a-5p } \downarrow \\
\text { miR-6821-3p } \downarrow \\
\end{array}$ & \begin{tabular}{|l} 
Diagnostic \\
biomarkers \\
of knee OA
\end{tabular} & [68] \\
\hline
\end{tabular}




\begin{tabular}{|c|c|c|c|c|c|c|c|}
\hline & & $\begin{array}{l}\text { extracellular } \\
\text { vesicles }\end{array}$ & $\begin{array}{l}\text { patients with OA and } \\
\text { without OA and between } \\
\text { male and female. }\end{array}$ & \begin{tabular}{|l|}
144 miRNAs \\
differentially \\
expressed in \\
females \\
in \\
miRNA array \\
miR-504-3p $\uparrow$ \\
(Only miRNA \\
to be up- \\
regulated in \\
both male and \\
female). \\
\end{tabular} & $\begin{array}{l}\text { (Significantly down- } \\
\text { regulated expression in } \\
\text { female OA compared to } \\
\text { female non-OA). }\end{array}$ & $\begin{array}{l}\text { in females } \\
\text { only. }\end{array}$ & \\
\hline $\begin{array}{l}\text { Human } \\
\text { synovial fluid }\end{array}$ & Knee & $\begin{array}{l}\text { Total small } \\
\text { RNAs from } \\
\text { synovial } \\
\text { fluid } \\
\text { supernatant. }\end{array}$ & \begin{tabular}{|c|} 
To examine the expression \\
of synovial fluid miR-140 \\
between non-OA and \\
radiographic \\
moderate and severe OA \\
(assessed by KL grading).
\end{tabular} & - & $\begin{array}{c}\text { miR-140 } \downarrow \\
\text { (with increasing } \\
\text { radiographic severity of } \\
\text { OA). }\end{array}$ & $\mid \begin{array}{ll}\text { Prognostic } \\
\text { biomarker of } \\
\text { knee OA } \\
\text { disease } \\
\text { progression. }\end{array}$ & {$[70]$} \\
\hline Human serum & $\begin{array}{l}\text { Knee and/or } \\
\text { hip }\end{array}$ & $\begin{array}{l}\text { Total RNA } \\
\text { from serum. }\end{array}$ & $\begin{array}{l}\text { Differential expression of } \\
\text { serum miRNAs between } \\
\text { patients with OA-related } \\
\text { knee or hip arthroplasty } \\
\text { compared to individuals } \\
\text { without arthroplasty. }\end{array}$ & $\begin{array}{l}12 \text { miRNAs } \\
\text { differentially } \\
\text { expressed in } \\
\text { miRNA array. }\end{array}$ & $\begin{array}{c}\text { let-7e } \downarrow \\
\text { (with increasing number } \\
\text { of hip/knee joint } \\
\text { replacement surgeries). }\end{array}$ & \begin{tabular}{|l|} 
Diagnostic \\
biomarker of \\
knee and/or \\
hip OA and \\
likelihood \\
for need of \\
knee and/or \\
hip \\
arthroplasty.
\end{tabular} & {$[71]$} \\
\hline $\begin{array}{l}\text { Human } \\
\text { plasma }\end{array}$ & Knee & $\begin{array}{l}\text { Total RNA } \\
\text { from plasma. }\end{array}$ & $\begin{array}{l}\text { Differential expression of } \\
\text { plasma miRNAs between } \\
\text { patients with radiographic } \\
\text { knee OA and patients } \\
\text { without clinical diagnosis } \\
\text { of OA } \\
\text { (assessed by KL grading). }\end{array}$ & $\begin{array}{l}12 \text { miRNAs } \\
\text { differentially } \\
\text { expressed in } \\
\text { miRNA array. }\end{array}$ & $\begin{array}{c}\text { miR-29c } \uparrow \\
\text { miR-93 } \uparrow \\
\text { miR-126 } \uparrow \\
\text { miR-184 } \uparrow \\
\text { miR-186 } \uparrow \\
\text { miR-195 } \uparrow \\
\text { miR-345 } \uparrow \\
\text { miR-885-5p } \uparrow \\
\text { miR-16 } \uparrow \\
\text { miR-146a } \uparrow \\
\text { (Up-regulated expression } \\
\text { in OA compared to non- } \\
\text { OA). }\end{array}$ & $\begin{array}{l}\text { Diagnostic } \\
\text { biomarkers } \\
\text { of knee OA. }\end{array}$ & {$[72]$} \\
\hline $\begin{array}{l}\text { Human } \\
\text { plasma }\end{array}$ & Knee & $\begin{array}{l}\text { Total RNA } \\
\text { from plasma. }\end{array}$ & $\begin{array}{l}\text { Differential expression of } \\
\text { plasma miRNAs between } \\
\text { patients with knee OA and } \\
\text { healthy controls (HC) } \\
\text { (assessed by 1986 } \\
\text { classification of knee OA } \\
\text { in diagnostic criteria of the } \\
\text { American Rheumatism } \\
\text { Association [137]). }\end{array}$ & $\begin{array}{l}70 \text { miRNAs } \\
\text { differentially } \\
\text { expressed in } \\
\text { miRNA array. }\end{array}$ & \begin{tabular}{|c} 
miR-19b-3p $\uparrow$ \\
miR-92a-3p $\uparrow$ \\
miR-122-5p $\uparrow$ \\
miR-486-5p $\uparrow$ \\
(Up-regulated expression \\
in OA compared to HC).
\end{tabular} & $\begin{array}{l}\text { Diagnostic } \\
\text { biomarkers } \\
\text { of knee OA. }\end{array}$ & [73] \\
\hline $\begin{array}{l}\text { Human blood } \\
\text { - PBMCs }\end{array}$ & Knee & $\begin{array}{l}\text { Total RNA } \\
\text { from } \\
\text { PBMCs. }\end{array}$ & $\begin{array}{l}\text { Differential expression of } \\
\text { PBMC-derived miRNA } \\
\text { between patients with RA, } \\
\text { knee OA and healthy } \\
\text { controls (HC) (assessed by } \\
1986 \text { classification of knee } \\
\text { OA in diagnostic criteria of } \\
\text { the American Rheumatism } \\
\text { Association [137]). }\end{array}$ & - & $\begin{array}{c}\text { miR-146a } \uparrow \\
\text { miR-155 } \uparrow \\
\text { miR-181a } \uparrow \\
\text { miR-223 } \uparrow \\
\text { (Significantly up- } \\
\text { regulated expression in } \\
\text { both RA and OA } \\
\text { compared to HC). } \\
\text { miR-146a } \downarrow \\
\text { miR-155 } \downarrow\end{array}$ & \begin{tabular}{|l|} 
Diagnostic \\
biomarkers \\
of knee OA \\
and RA. \\
Assessment \\
of \\
expression \\
required to \\
differentiate \\
OA from RA \\
$-\quad$ lower
\end{tabular} & {$[74]$} \\
\hline
\end{tabular}




\begin{tabular}{|c|c|c|c|c|c|c|c|}
\hline & & & $\mid \begin{array}{lr}\text { Differential } & \text { expression of } \\
\text { PBMC-derived } & \text { miRNA } \\
\text { between } & \text { radiographic } \\
\text { stages of OA } & \text { (assessed by } \\
\text { KL grading). }\end{array}$ & & $\begin{array}{c}\text { miR-223 } \downarrow \\
\text { (Significantly up- } \\
\text { regulated expression in } \\
\text { RA when compared to } \\
\text { OA). } \\
\text { miR-146a } \uparrow \text { in early OA } \\
\text { miR-223 } \uparrow \text { in early OA } \\
\text { miR-155 } \downarrow \text { in early OA }\end{array}$ & $\begin{array}{l}\text { expression } \\
\text { in OA than } \\
\text { RA. } \\
\text { miR-146a } \\
\text { and miR-223 } \\
\text { biomarkers } \\
\text { of early OA } \\
\text { miR-155 } \\
\text { biomarker of } \\
\text { late-stage } \\
\text { OA. }\end{array}$ & \\
\hline \multicolumn{8}{|c|}{ IncRNA } \\
\hline $\begin{array}{l}\text { Human } \\
\text { synovial fluid }\end{array}$ & $\begin{array}{l}\text { Temporoma } \\
\text { ndibular } \\
\text { joint }(\mathrm{TMJ})\end{array}$ & $\begin{array}{l}\text { Total RNA } \\
\text { from } \\
\text { synovial } \\
\text { fluid. }\end{array}$ & 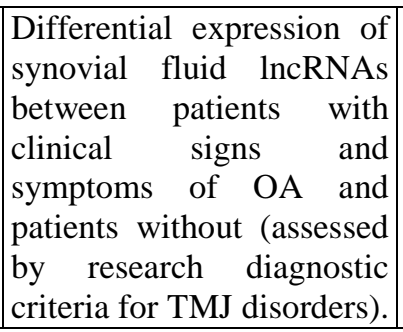 & - & $\begin{array}{l}\text { HOTAIR } \uparrow \\
\text { (Significantly up- } \\
\text { regulated in OA } \\
\text { compared to normal } \\
\text { controls). }\end{array}$ & $\begin{array}{l}\text { Diagnostic } \\
\text { biomarker of } \\
\text { TMJ OA. }\end{array}$ & [79] \\
\hline \multicolumn{8}{|c|}{ snoRNA } \\
\hline Human serum & $\begin{array}{l}\text { Anterior } \\
\text { cruciate } \\
\text { ligament } \\
(\text { ACL }) \\
\text { knee. }\end{array}$ & $\begin{array}{l}\text { Total RNA } \\
\text { from serum. }\end{array}$ & 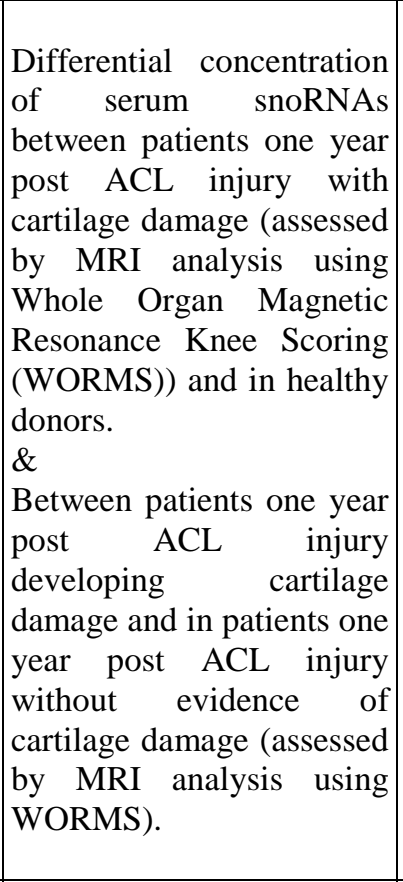 & - & $\begin{array}{c}\text { U48 } \uparrow \\
\text { (Significantly higher } \\
\text { levels in patients with } \\
\text { ACL injury with } \\
\text { cartilage damage } \\
\text { compared to healthy } \\
\text { donors). } \\
\text { U38 } \uparrow \\
\text { (Significantly higher } \\
\text { levels in patients with } \\
\text { ACL injury with } \\
\text { cartilage damage } \\
\text { compared to healthy } \\
\text { donors) } \\
\& \\
\text { Significantly higher } \\
\text { levels in patients with } \\
\text { greater cartilage damage } \\
\text { compared to patients } \\
\text { with minor cartilage } \\
\text { damage). }\end{array}$ & $\begin{array}{l}\text { Diagnostic } \\
\text { biomarkers } \\
\text { of cartilage } \\
\text { damage. } \\
\text { U38 can } \\
\text { differentiate } \\
\text { between } \\
\text { minor and } \\
\text { greater } \\
\text { cartilage } \\
\text { damage } \\
\text { induced by } \\
\text { ACL injury } \\
\text { - U38 } \\
\text { biomarker of } \\
\text { early ACL } \\
\text { induced } \\
\text { damage. }\end{array}$ & [86] \\
\hline Mice serum & $\begin{array}{l}\text { Not stated in } \\
\text { study }\end{array}$ & $\begin{array}{l}\text { Total RNA } \\
\text { from serum. }\end{array}$ & $\begin{array}{l}\text { Differential expression of } \\
\text { serum snoRNAs between } \\
\text { old sham mice and mice } \\
\text { with r experimentally } \\
\text { induced destabilisation of } \\
\text { the medial meniscus } \\
(\mathrm{DMM}) \text {. }\end{array}$ & $\begin{array}{l}18 \text { snoRNAs } \\
\text { differentially } \\
\text { expressed } \\
\text { snoRNASeq. }\end{array}$ & $\begin{array}{c}\text { SNORD116 } \uparrow \\
\text { SNORA64 } \uparrow \\
\text { U3 } \uparrow \\
\text { (Significantly up- } \\
\text { regulated in } \\
\text { experimentally induced } \\
\text { OA compared to control } \\
\text { sham mice). } \\
\text { SNORD46 } \downarrow \\
\text { (Significantly down- } \\
\text { regulated in } \\
\text { experimentally induced } \\
\text { OA compared to control } \\
\text { sham mice). }\end{array}$ & $\begin{array}{l}\text { Diagnostic } \\
\text { biomarkers } \\
\text { of OA. }\end{array}$ & [87] \\
\hline
\end{tabular}




\begin{tabular}{|c|c|c|c|c|c|c|c|}
\hline Horse serum & $\begin{array}{l}\text { Not stated in } \\
\text { study }\end{array}$ & Serum & 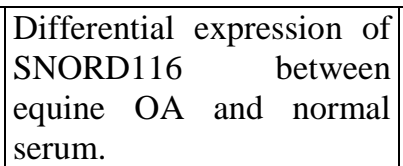 & - & $\begin{array}{c}\text { SNORD116 } \uparrow \\
\text { (Significantly up- } \\
\text { regulated in OA } \\
\text { compared to non-OA). }\end{array}$ & $\begin{array}{l}\text { Diagnostic } \\
\text { biomarker of } \\
\text { OA. }\end{array}$ & [87] \\
\hline \multicolumn{8}{|c|}{ DNA } \\
\hline Human serum & $\begin{array}{l}\text { Not stated in } \\
\text { study }\end{array}$ & $\begin{array}{ll}\text { DNA } & \text { from } \\
\text { serum } & \end{array}$ & $\begin{array}{l}\text { Differential DNA levels in } \\
\text { patients with RA compared } \\
\text { to patients with OA. }\end{array}$ & - & $\begin{array}{c}\text { DNA level } \downarrow \\
\text { (Significant increase in } \\
\text { concentration in RA } \\
\text { compared to OA). }\end{array}$ & $\begin{array}{l}\text { Differentiate } \\
\text { between OA } \\
\text { and RA. }\end{array}$ & {$[96]$} \\
\hline $\begin{array}{l}\text { Human } \\
\text { synovial fluid }\end{array}$ & $\begin{array}{l}\text { Not stated in } \\
\text { study }\end{array}$ & $\begin{array}{l}\text { DNA from } \\
\text { synovial } \\
\text { fluid }\end{array}$ & $\begin{array}{l}\text { Differential DNA levels in } \\
\text { patients with RA compared } \\
\text { to patients with OA. }\end{array}$ & - & $\begin{array}{c}\text { DNA level } \downarrow \\
\text { (Significant increase in } \\
\text { concentration in RA } \\
\text { compared to OA). }\end{array}$ & $\begin{array}{l}\text { Differentiate } \\
\text { between OA } \\
\text { and RA. }\end{array}$ & [96] \\
\hline $\begin{array}{l}\text { Human } \\
\text { plasma }\end{array}$ & $\begin{array}{l}\text { Not stated in } \\
\text { study }\end{array}$ & $\begin{array}{l}\text { cfDNA from } \\
\text { plasma }\end{array}$ & $\begin{array}{l}\text { Differential concentration } \\
\text { of circulating cfDNA in } \\
\text { patients with RA compared } \\
\text { to patient with OA. }\end{array}$ & - & $\begin{array}{c}\text { cfDNA level } \downarrow \\
\text { (Significant increase in } \\
\text { concentration in RA } \\
\text { compared to OA). }\end{array}$ & $\begin{array}{l}\text { Differentiate } \\
\text { between OA } \\
\text { and RA. }\end{array}$ & [97] \\
\hline \multicolumn{8}{|c|}{ PBMCs } \\
\hline Human blood & Knee & $\begin{array}{l}\text { Total RNA } \\
\text { from cellular } \\
\text { fraction of } \\
\text { blood. }\end{array}$ & $\mid \begin{array}{lr}\text { Differential } & \text { gene } \\
\text { expression of total cellular } \\
\text { blood between patients } \\
\text { with mild OA and control } \\
\text { subjects (assessed by } \\
\text { arthroscopic } r \text { scoring } \\
\text { method [138]). }\end{array}$ & $\mid \begin{array}{l}3,543 \\
\text { differentially } \\
\text { expressed in } \\
\text { genes } \\
\text { cDNA } \\
\text { microarray. }\end{array}$ & $\begin{array}{c}\text { HSPCA mRNA } \downarrow \\
\text { IKBKAP mRNA } \downarrow \\
\text { ILI3RA1 mRNA } \downarrow \\
\text { LAMC1 mRNA } \downarrow \\
\text { TNFAIP6 mRNA } \downarrow \\
\text { PF4 mRNA } \downarrow \\
\text { (Significantly down- } \\
\text { regulated in mild knee } \\
\text { OA compared to } \\
\text { controls). }\end{array}$ & $\begin{array}{l}\text { Diagnostic } \\
\text { biomarkers } \\
\text { of mild knee } \\
\text { OA. }\end{array}$ & [106] \\
\hline Human blood & Knee & $\begin{array}{l}\text { Total RNA } \\
\text { from } \\
\text { PBMCs. }\end{array}$ & $\begin{array}{l}\text { Correlation of OA patients } \\
\text { which identified as having } \\
\text { up-regulated cytokine } \\
\text { expression (from blood- } \\
\text { derived PBMCs RNA) } \\
\text { compared to OA patients } \\
\text { identified as having low } \\
\text { cytokine expression, and } \\
\text { OA radiographic } \\
\text { progression (assessed by }\end{array}$ & - & $\begin{array}{c}I L-1 \beta \text { mRNA } \uparrow \\
T N F \alpha \text { mRNA } \uparrow \\
I L-6 \text { mRNA } \uparrow \\
I L-8 \text { mRNA } \uparrow \\
C O X-2 \text { mRNA } \uparrow \\
\text { (Significant up- } \\
\text { regulation in } \\
\text { inflammatory OA } \\
\text { subclass). }\end{array}$ & $\begin{array}{l}\text { Biomarkers } \\
\text { of } \\
\text { inflammator } \\
\text { y knee OA } \\
\text { with } \\
\text { increased } \\
\text { risk of rapid } \\
\text { radiographic } \\
\text { progression. }\end{array}$ & [108] \\
\hline Human blood & $\begin{array}{l}\text { Primary OA } \\
\text { - at multiple } \\
\text { joint sites in } \\
\text { the hand, or } \\
\text { at least two } \\
\text { joints from } \\
\text { hand, spine, } \\
\text { knee or hip. }\end{array}$ & $\begin{array}{l}\text { Total RNA } \\
\text { from } \\
\text { PBMCs. }\end{array}$ & $\begin{array}{l}\text { Differential } \\
\text { expression of } \begin{array}{r}\text { gene } \\
\text { derived PBMCs }\end{array} \\
\text { OA patients } \\
\text { control subjects } \\
\text { by definition of } \\
\text { diagnosis by the American } \\
\text { College of Rheumatology } \\
[137]) \text {. }\end{array}$ & $\begin{array}{l}679 \text { genes and } \\
15 \text { ncRNAs } \\
\text { differentially } \\
\text { expressed in } \\
\text { microarray. }\end{array}$ & $\begin{array}{c}\text { GPR18 mRNA } \uparrow \\
Z N F 564 \text { mRNA } \uparrow \\
\text { XNF20 mRNA } \uparrow \\
\text { RIPK1 mRNA } \uparrow \\
\text { ADRB2 mRNA } \uparrow \\
\text { PELO mRNA } \uparrow \\
\text { SIAH1 mRNA } \uparrow \\
\text { SLA mRNA } \uparrow \\
\text { PLEKHF1 mRNA } \uparrow \\
\text { CASP3 mRNA } \uparrow \\
\text { RABEP1 mRNA } \uparrow \\
\text { FADD mRNA } \uparrow \\
\text { CLK1 mRNA } \uparrow \\
\text { ESF2 mRNA } \uparrow \\
\text { Significant up- } \\
\text { regulation in OA } \\
\text { compared to non-OA). } \\
- \\
\text { ATF4 mRNA } \downarrow \\
\text { SFRS5 mRNA } \downarrow \\
\text { CDKN2D mRNA } \downarrow \\
\text { PPP1R15A mRNA } \downarrow\end{array}$ & $\begin{array}{l}\text { Diagnostic } \\
\text { biomarkers } \\
\text { of OA. }\end{array}$ & [107] \\
\hline
\end{tabular}




\begin{tabular}{|c|c|c|c|c|c|c|c|}
\hline & & & & & $\begin{array}{c}\text { OSM mRNA } \downarrow \\
\text { GSTM2 mRNA } \downarrow \\
\text { ERG1 mRNA } \downarrow \\
\text { IL8 mRNA } \downarrow \\
\text { (Significant down- } \\
\text { regulation in OA } \\
\text { compared to non-OA). }\end{array}$ & & \\
\hline Rat blood & \begin{tabular}{|l} 
Monosodiu \\
$\mathrm{m}$ \\
iodoacetate \\
(MIA)- \\
induced OA \\
of the knee \\
joint.
\end{tabular} & $\begin{array}{l}\text { Total RNA } \\
\text { from whole } \\
\text { blood. }\end{array}$ & $\begin{array}{l}\text { Time course gene } \\
\text { expression of MIA induced } \\
\text { OA and comparison of } \\
\text { microarray dataset to } \\
\text { microarray dataset } \\
\text { obtained from the human } \\
\text { GARP study [107]. }\end{array}$ & \begin{tabular}{|l|}
$72 \quad$ genes \\
differentially \\
expressed \\
during \\
development \\
of MIA - \\
induced OA in \\
microarray.
\end{tabular} & $\begin{array}{c}\text { Tnk2 mRNA } \\
\text { Wdr37 mRNA } \\
\text { Kctd2 mRNA } \\
\text { (Differentially expressed } \\
\text { in both rat model and } \\
\text { OA patients). }\end{array}$ & $\begin{array}{l}\text { Diagnostic } \\
\text { biomarkers } \\
\text { of OA. }\end{array}$ & [109] \\
\hline Human blood & Knee & $\begin{array}{l}\text { DNA from } \\
\text { PBMCs. }\end{array}$ & $\begin{array}{llr}\text { Differential methylation of } \\
\text { CpG sites of blood-derived } \\
\text { PBMC } & \text { DNA } & \text { between } \\
\text { patients } & \text { with } & \text { rapid } \\
\text { progressive } & \text { OA } & \text { and } \\
\text { patients } & \text { with } & \text { non- } \\
\text { progressive } & \text { OA } & \text { assessed } \\
\text { by radiographic joint } & \text { space } \\
\text { loss at follow-up and need } \\
\text { for arthroplasty). }\end{array}$ & - & $\begin{array}{l}\mathbf{4 4} \text { CpG sites } \\
\text { (Differentially } \\
\text { methylated between } \\
\text { rapid and non- } \\
\text { progressive OA). }\end{array}$ & $\begin{array}{l}\text { Methylation } \\
\text { status as a } \\
\text { biomarker } \\
\text { for } \\
\text { predicting } \\
\text { future } \\
\text { radiographic } \\
\text { progression } \\
\text { of knee OA. }\end{array}$ & [110] \\
\hline
\end{tabular}

Table 1. Extracellular carrier-associated and extracellular carrier-free genomic material with the potential to serve as genomic biomarkers in OA. $\uparrow$ - Up-regulated expression/concentration/level in OA. $\downarrow$ - Down-regulated expression/concentration/level in OA. 


\begin{tabular}{|c|c|}
\hline $\begin{array}{c}\text { Functional } \\
\text { non-coding } \\
\text { RNA (ncRNA) }\end{array}$ & Definition and function \\
\hline $\begin{array}{c}\text { MicroRNA } \\
\text { (miRNA) }\end{array}$ & $\begin{array}{l}\text { MiRNA are single stranded ncRNA of approximately } 22 \text { nucleotides in length. MiRNA function by binding to locations } \\
\text { within mRNA, typically within the 3'UTR, following RNA transcription [47]. The seed sequence of the miRNA is } \\
\text { responsible for miRNA-mRNA binding and is a sequence of at least } 6 \text { nucleotides positioned at the 5' end of the } \\
\text { miRNA and base pairs with perfect complementarity to a target sequence within the mRNA 3'UTR [139]. The binding } \\
\text { of miRNA to mRNA, in the cytoplasm, prevents mRNA translation in the synthesis of protein. MiRNA is therefore } \\
\text { capable of down-regulating protein expression through effective mRNA targeting [48]. }\end{array}$ \\
\hline $\begin{array}{l}\text { Long non- } \\
\text { coding RNA } \\
\text { (lncRNA) }\end{array}$ & $\begin{array}{l}\text { The definition of lncRNAs is limited to ncRNAs of more than } 200 \text { nucleotides in length which lack protein coding } \\
\text { capability [75]. LncRNAs have been classified according to molecular mechanism and can be subtyped as having } \\
\text { signalling, decoy, guide, scaffold and enhancer roles [77]. LncRNAs can also be subtyped according to their position } \\
\text { and direction of transcription relative to other genes and can be classified into subtypes including intergenic, intronic, } \\
\text { antisense, overlapping, processed and bidirectional lncRNAs [78]. For example lncRNAs include some cis-natural } \\
\text { antisense transcripts (NATs), antisense ncRNA of sequence complementarity to coding RNA from the same genomic } \\
\text { locus, which function to regulate expression of sense transcripts. LncRNAs include some trans-NATs, antisense } \\
\text { ncRNA of sequence complementarity to coding RNA from a distal genomic locus, which functions to regulate sense } \\
\text { transcripts. LncRNAs include long intergenic ncRNA (lincRNA) which are encoded in intergenic regions of DNA, } \\
\text { sense overlapping lncRNAs which are transcribed from the same strand of DNA as another transcript, sense intronic } \\
\text { lncRNAs which are encoded in introns of coding genes and processed lncRNAs which can be spliced and/or } \\
\text { polyadenylated [76]. Different lncRNAs are involved in different biological functions in both the nucleus and } \\
\text { cytoplasm. LncRNAs have been observed to have roles in chromatin modification through recruitment of chromatin } \\
\text { modifying complexes. LncRNAs have been observed to have roles in transcriptional regulation, for example by } \\
\text { functioning as decoys for transcription factors, functioning as transcription factor co-regulators and by inhibiting } \\
\text { formation of transcription machinery. LncRNAs have also been observed to have roles in post-transcriptional } \\
\text { regulation, for example by interacting with splicing factors and hindering spliceosome formation, by increasing or } \\
\text { decreasing mRNA stability, by masking miRNA binding sites in mRNA } 3 \text { 'UTR and by acting as miRNA sponges to } \\
\text { prevent miRNA binding to target mRNA [140]. }\end{array}$ \\
\hline
\end{tabular}

SnRNA, located in the nucleus, function in the process of splicing, aiding in the processing of pre-mRNA to mature Small nuclear RNA (snRNA) mRNA in the removal of introns. SnRNAs associate with small nuclear ribonucleoproteins to form the spliceosome. The snRNAs function as ribozymes, mediating base pairing with RNA [141]. Spliceosomal snRNAs include U1, U2, U4, U5, and U6 have roles in substrate recognition at splice sites, in lariat formation and splicing catalysis [142].

SnoRNAs, a sub-class of snRNA located in the nucleus, are involved with post-transcriptional modification by means Small nucleolar of methylation or pseudouridylation of non-coding RNA including snRNA, rRNA and tRNA. SnoRNAs are divided into two classes, SNORDs and SNORAs, dependent on their structural features and sequence [84]. SNORDs are box C/D snoRNAs, are approximately 70-120 nucleotides in length and contain two conserved elements: box C (PuUGAUGA) located at the 5'- termini and box D (CUGA) located at the 3'-termini. The sequence elements form 


\begin{tabular}{|c|c|}
\hline & $\begin{array}{l}\text { stem-bulge-stem folding domains which serve as scaffolds for small nucleolar ribonucleoprotein (snoRNP) assembly. } \\
\text { The Box C/D snoRNA: snoRNP complex catalyses site specific 2'-O-methylation in target RNA [85]. SNORAs are } \\
\text { box H/ACA snoRNAs are hairpin-hinge-hairpin-tail structures which contain two conserved elements: box H } \\
\text { (ANANNA) (N is any nucleotide) and box ACA which is a trinucleotide located } 3 \text { nucleotides upstream of the 3'- } \\
\text { terminus. Box H/ACA snoRNAs associate with snoRNPs which catalyse pseudouridylation in target RNA [85]. Cajal- } \\
\text { body-specific RNAs (scaRNAs) are snoRNAs which commonly contain features of both SNORDs and SNORAs and } \\
\text { also contain an element called the Cajal body box (CAB box). ScaRNAs are located within Cajal bodies and are } \\
\text { involved with methylation and pseudouridylation of spliceosomal snRNAs [143]. In addition to their role in the } \\
\text { modification of other ncRNA, snoRNAs can be further processed to generate smaller fragments known as sno-derived } \\
\text { RNAs (sdRNAs) which possess miRNA-like features [144], [145]. }\end{array}$ \\
\hline $\begin{array}{c}\text { Transfer RNA } \\
\text { (tRNA) }\end{array}$ & $\begin{array}{l}\text { tRNAs, approximately } 76 \text { nucleotides in length, are fundamental to the process of protein biosynthesis and participate } \\
\text { in translating codons of mRNA into corresponding amino acids and for each canonical amino acid a subset of tRNA } \\
\text { species exist [146]. tRNAs are aminoacylated by aminoacyl-tRNA synthetase and the resultant aminoacyl-tRNAs are } \\
\text { directed to the ribosome where the tRNA locates to the tRNA binding site. At the tRNA binding site the anticodon } \\
\text { sequence in the tRNA base-pairs with the codon sequence in the mRNA, which specifies the aminoacylated attached } \\
\text { amino acid [147]. tRNAs exhibit a cloverleaf-shaped secondary structure which ultimately folds into an L-shaped } \\
\text { tertiary structure which is fundamental to its role [146]. }\end{array}$ \\
\hline $\begin{array}{c}\text { Transfer RNA- } \\
\text { derived RNA } \\
\text { fragments } \\
\text { (tRFs) }\end{array}$ & $\begin{array}{l}\text { tRFs are processed from pre-tRNA and mature t-RNA, generated from all parts of the tRNA molecule. tRFs were } \\
\text { assumed to be inert but have recently been observed to be produced to function in processes including stress response, } \\
\text { translation inhibition and proliferation [148]. }\end{array}$ \\
\hline $\begin{array}{l}\text { Ribosomal RNA } \\
\text { (rRNA) }\end{array}$ & $\begin{array}{l}\text { rRNA ranges in size from } 120 \text { to } 5000 \text { nucleotides and are a key component of ribosomes and therefore play a } \\
\text { fundamental role in protein biosynthesis. Ribosomes are composed of proteins and several different rRNA molecules } \\
\text { which are organised into a small subunit and a large subunit [147]. The ribosome comprises of rRNA which possesses } \\
\text { ribozymal activity. The small subunit of the ribosome mediates the interactions between the tRNA anticodons and } \\
\text { mRNA codons and the large subunit catalyses the formation of the peptide bond, with rRNA } 28 \mathrm{~S} \text { being responsible for } \\
\text { peptidyl transferase activity of the ribosome [149]. }\end{array}$ \\
\hline $\begin{array}{c}\text { Circular RNA } \\
\text { (circRNA) }\end{array}$ & $\begin{array}{l}\text { CircRNA is non-linear, with the } 3 \text { ' and } 5 \text {, ends joined together resulting in a circular structure, generated from the } \\
\text { backsplicing of introns and/or exons. CircRNA has been proposed to be stable as a result of its structure which prevents } \\
\text { degradation by RNA exonucleases and therefore is abundant in the cytoplasm. CircRNAs have been suggested to } \\
\text { function as miRNA sponges and therefore may play a role in gene expression regulation by regulating miRNA } \\
\text { expression [150]. Additional potential roles for circRNA include interacting with RNA binding proteins, modulating } \\
\text { mRNA stability and regulating gene transcription [151]. }\end{array}$ \\
\hline $\begin{array}{l}\text { Piwi-interacting } \\
\text { RNA (piRNA) }\end{array}$ & $\begin{array}{l}\text { piRNAs are 24-31 nucleotides in length and interact with PIWI proteins. PIWI proteins and piRNA constitute piRNA- } \\
\text { induced silencing complexes which function to repress transposons [152]. piRNAs are enriched in germline tissues, } \\
\text { and through the silencing of mobile elements, are thought to prevent accumulation of genome changes [153]. }\end{array}$ \\
\hline
\end{tabular}




\begin{tabular}{|c|l|}
\hline $\begin{array}{c}\text { Vault RNA } \\
\text { (vtRNA) }\end{array}$ & $\begin{array}{l}\text { vtRNAs are approximately } 80 \text { to } 150 \text { nucleotides in length and are associated with vault particles. Vault particles are } \\
\text { large cytoplasmic ribonucleoproteins which may have roles in intracellular nucleocytoplasmic transport [154], } \\
\text { intracellular detoxification, apoptosis resistance, signalling, DNA damage repair, innate immune response and } \\
\text { formation of the nuclear pore complex [155]. }\end{array}$ \\
\hline Y RNA & $\begin{array}{l}\text { Y RNAs vary in length between approximately } 83 \text { and } 112 \text { nucleotides and are folded into conserved stem-loop- } \\
\text { structures. Functions for Y RNA have been proposed and include cell stress response and proliferation regulation, } \\
\text { DNA replication and small RNA quality control. Y RNA are associated with different core protein s, for example } \\
\text { the association of Y RNA with Ro60 [156] }\end{array}$ \\
\hline
\end{tabular}

Table 2. Definitions of functional ncRNAs. 


\section{References}

1. Mobasheri, A., et al., The role of metabolism in the pathogenesis of osteoarthritis. Nat Rev Rheumatol, 2017. 13(5): p. 302-311.

2. Mobasheri, A., et al., Osteoarthritis Year in Review 2016: biomarkers (biochemical markers). Osteoarthritis and Cartilage, 2017. 25(2): p. 199-208.

3. Robinson, W.H., et al., Low-grade inflammation as a key mediator of the pathogenesis of osteoarthritis. Nature reviews. Rheumatology, 2016. 12(10): p. 580-592.

4. Budd, E., et al., MiR-146b is down-regulated during the chondrogenic differentiation of human bone marrow derived skeletal stem cells and up-regulated in osteoarthritis. Scientific Reports, 2017. 7: p. 46704.

5. Loeser, R.F., et al., Osteoarthritis: a disease of the joint as an organ. Arthritis \& Rheumatology, 2012. 64(6): p. 1697-1707.

6. Cross, M., et al., The global burden of hip and knee osteoarthritis: estimates from the Global Burden of Disease 2010 study. Annals of the Rheumatic Diseases, 2014.

7. Glyn-Jones, S., et al., Osteoarthritis. The Lancet, 2015. 386(9991): p. 376-387.

8. Arthritis Research UK., State-of-musculoskeletal-health-2017.PDF. Available from: https://www.arthritisresearchuk.org/arthritis-information/data-and-statistics/state-ofmusculoskeletal-health.aspx

9. $\quad$ Osteoarthritis Reseach Society International., OARSI white paper OA serious disease_121416_1.pdf. 2016. Available from:

https://www.oarsi.org/sites/default/files/docs/2016/oarsi_white_paper_oa_serious_disease_12 1416_1.pdf

\section{•• The Osteoarthritis Research Society International white paper submitted to the FDA to highlight the seriousness of $\mathrm{OA}$ and the need for effective therapies.}

10. Mobasheri, A., The Future of Osteoarthritis Therapeutics: Targeted Pharmacological Therapy. Current Rheumatology Reports, 2013. 15(10): p. 364.

11. Mobasheri, A. and Y. Henrotin, Biomarkers of (osteo)arthritis. Biomarkers, 2015. 20(8): p. 513-518.

12. Laslett, L.L., et al., Measuring Disease Progression in Osteoarthritis. Current Treatment Options in Rheumatology, 2016. 2(2): p. 97-110.

13. Hunter, D.J., J.J. McDougall, and F.J. Keefe, The symptoms of $O A$ and the genesis of pain. Rheumatic diseases clinics of North America, 2008. 34(3): p. 623-643.

14. Heidari, B., Knee osteoarthritis prevalence, risk factors, pathogenesis and features: Part I. Caspian Journal of Internal Medicine, 2011. 2(2): p. 205-212.

15. Emans, P.J. and L. Peterson, Developing Insights in Cartilage Repair. 2013: Springer London. 
16. Hunter, D.J., V.B. Kraus, and S. Hoffmann, FNIH Osteoarthritis Biomarkers Consortium Project.

https://www.oarsi.org/sites/default/files/library/2013/pdf/fnih oa biomarkers project update. pdf, 2013.

17. Luyten, F.P., et al., Definition and classification of early osteoarthritis of the knee. Knee Surg Sports Traumatol Arthrosc, 2012. 20(3): p. 401-6.

18. Ryd, L., et al., Pre-Osteoarthritis: Definition and Diagnosis of an Elusive Clinical Entity. Cartilage, 2015. 6(3): p. 156-165.

- This study introduces the definition of pre-OA, OA which is established at the cellular level only, prior to changes in cartilage structure.

19. Nguyen, L., et al., Review of Prospects of Biological Fluid Biomarkers in Osteoarthritis. International Journal of Molecular Sciences, 2017. 18(3): p. 601.

20. Fernandez-Puente, P., et al., Discovery of biomarkers for osteoarthritis using proteomic technologies.

2015. Available from: http://www.smgebooks.com/osteoarthritis/chapters/OAS-15-02.pdf

21. Stastna, M. and J.E. Van Eyk, Secreted proteins as a fundamental source for biomarker discovery. Proteomics, 2012. 12(4-5): p. 722-735.

22. Clutterbuck, A.L., et al., High throughput proteomic analysis of the secretome in an explant model of articular cartilage inflammation. Journal of Proteomics, 2011. 74(5): p. 704-715.

23. Fernández-Puente, P., et al., Identification of a Panel of Novel Serum Osteoarthritis Biomarkers. Journal of Proteome Research, 2011. 10(11): p. 5095-5101.

24. Gobezie, R., et al., High abundance synovial fluid proteome: distinct profiles in health and osteoarthritis. Arthritis Res Ther, 2007. 9(2): p. R36.

25. Han, M., et al., Identification of Osteoarthritis Biomarkers by Proteomic Analysis of Synovial Fluid. Journal of International Medical Research, 2012. 40(6): p. 2243-2250.

26. Ritter, S.Y., et al., Proteomic Analysis of Synovial Fluid From the Osteoarthritic Knee: Comparison With Transcriptome Analyses of Joint Tissues. Arthritis \& Rheumatism, 2013. 65(4): p. 981-992.

27. Balakrishnan, L., et al., Proteomic analysis of human osteoarthritis synovial fluid. Clinical Proteomics, 2014. 11(1): p. 6.

28. Liao, W., et al., Proteomic analysis of synovial fluid as an analytical tool to detect candidate biomarkers for knee osteoarthritis. International Journal of Clinical and Experimental Pathology, 2015. 8(9): p. 9975-9989.

29. Ritter, S.Y., et al., Mass spectrometry assays of plasma biomarkers to predict radiographic progression of knee osteoarthritis. Arthritis Research \& Therapy, 2014. 16(5): p. 456. 
30. Fukuda, I., et al., Potential plasma biomarkers for progression of knee osteoarthritis using glycoproteomic analysis coupled with a 2D-LC-MALDI system. Proteome Science, 2012. 10: p. 36-36.

31. Henrotin, Y., et al., Fibulin 3 peptides Fib3-1 and Fib3-2 are potential biomarkers of osteoarthritis. Arthritis \& Rheumatism, 2012. 64(7): p. 2260-2267.

32. Lourido, L., et al., Discovery of circulating proteins associated to knee radiographic osteoarthritis. Sci Rep, 2017. 7(1): p. 137.

33. International conference on harmonisation of technical requirements for registration of pharmaceuticals for human use., Definitions for genomic biomarkers, pharmacogenomics, pharmacogenetics, genomic data and sample coding categories E15. 2007. Available from: http://www.ich.org/fileadmin/Public_Web_Site/ICH_Products/Guidelines/Efficacy/E15/Step4 /E15_Guideline.pdf

34. Henrotin, Y., et al., Osteoarthritis biomarkers derived from cartilage extracellular matrix: Current status and future perspectives. Annals of Physical and Rehabilitation Medicine, 2016. 59(3): p. 145-148.

35. Freedman, J.E., et al., Diverse human extracellular RNAs are widely detected in human plasma. Nature Communications, 2016. 7: p. 11106.

- This study demonstrates the existance of RNA within the extracellular space, including miRNA, piRNA ad snRNA.

36. Abels, E.R. and X.O. Breakefield, Introduction to Extracellular Vesicles: Biogenesis, RNA Cargo Selection, Content, Release, and Uptake. Cellular and Molecular Neurobiology, 2016. 36(3): p. 301-312.

37. Sorrentino, S., The eight human "canonical" ribonucleases: Molecular diversity, catalytic properties, and special biological actions of the enzyme proteins. FEBS Letters, 2010. 584(11): p. 2194-2200.

38. Cheng, L., et al., Exosomes provide a protective and enriched source of miRNA for biomarker profiling compared to intracellular and cell-free blood. J Extracell Vesicles, 2014. 3.

39. Patton, J.G., et al., Biogenesis, delivery, and function of extracellular RNA. Journal of Extracellular Vesicles, 2015. 4: p. 10.3402/jev.v4.27494.

40. Gold, B., et al., Do Circulating Tumor Cells, Exosomes, and Circulating Tumor Nucleic Acids Have Clinical Utility?: A Report of the Association for Molecular Pathology. The Journal of Molecular Diagnostics : JMD, 2015. 17(3): p. 209-224.

41. Chi, K.R., The dark side of the human genome. Nature, 2016. 538(7624): p. 275-277.

42. Patrushev, L.I. and T.F. Kovalenko, Functions of noncoding sequences in mammalian genomes. Biochemistry (Mosc), 2014. 79(13): p. 1442-69.

43. Hombach, S. and M. Kretz, Non-coding RNAs: Classification, Biology and Functioning. Adv Exp Med Biol, 2016. 937: p. 3-17. 
44. Kaikkonen, M.U., M.T.Y. Lam, and C.K. Glass, Non-coding RNAs as regulators of gene expression and epigenetics. Cardiovascular Research, 2011. 90(3): p. 430-440.

45. Esteller, M., Non-coding RNAs in human disease. Nat Rev Genet, 2011. 12(12): p. 861-874.

46. Shi, T., G. Gao, and Y. Cao, Long Noncoding RNAs as Novel Biomarkers Have a Promising Future in Cancer Diagnostics. Disease Markers, 2016. 2016: p. 9085195.

47. Felekkis, K., et al., microRNAs: a newly described class of encoded molecules that play a role in health and disease. Hippokratia, 2010. 14(4): p. 236-240.

48. Pasquinelli, A.E., MicroRNAs and their targets: recognition, regulation and an emerging reciprocal relationship. Nat Rev Genet, 2012. 13(4): p. 271-282.

49. Tardif, G., et al., Regulation of the IGFBP-5 and MMP-13 genes by the microRNAs miR-140 and miR-27a in human osteoarthritic chondrocytes. BMC Musculoskeletal Disorders, 2009. 10: p. 148-148.

50. Matsukawa, T., et al., MicroRNA-125b regulates the expression of aggrecanase-1 (ADAMTS4) in human osteoarthritic chondrocytes. Arthritis Research \& Therapy, 2013. 15(1): p. R28R28.

51. Li, Z., et al., Overexpression of microRNA-210 promotes chondrocyte proliferation and extracellular matrix deposition by targeting HIF-3alpha in osteoarthritis. Mol Med Rep, 2016. 13(3): p. 2769-76.

52. Song, J., et al., MicroRNA-222 regulates MMP-13 via targeting HDAC-4 during osteoarthritis pathogenesis. BBA Clin, 2015. 3: p. 79-89.

53. Akhtar, N. and T.M. Haqqi, MicroRNA-199a* regulates the expression of cyclooxygenase-2 in human chondrocytes. Ann Rheum Dis, 2012. 71(6): p. 1073-80.

54. Park, S.J., E.J. Cheon, and H.A. Kim, MicroRNA-558 regulates the expression of cyclooxygenase-2 and IL-1beta-induced catabolic effects in human articular chondrocytes. Osteoarthritis Cartilage, 2013. 21(7): p. 981-9.

55. Wang, G., et al., MicroRNA-411 inhibited matrix metalloproteinase 13 expression in human chondrocytes. American Journal of Translational Research, 2015. 7(10): p. 2000-2006.

56. Ji, Q., et al., miR-105/Runx2 axis mediates FGF2-induced ADAMTS expression in osteoarthritis cartilage. Journal of Molecular Medicine, 2016. 94(6): p. 681-694.

57. Zhang, G., et al., MiR-502-5p inhibits IL-1 $\beta$-induced chondrocyte injury by targeting TRAF2. Cellular Immunology, 2016. 302: p. 50-57.

58. Song, J., et al., MicroRNA-181b regulates articular chondrocytes differentiation and cartilage integrity. Biochem Biophys Res Commun, 2013. 431(2): p. 210-4.

59. Chang, T., et al., MicroRNA-30a promotes extracellular matrix degradation in articular cartilage via downregulation of Sox9. Cell Proliferation, 2016. 49(2): p. 207-218.

60. Swingler, T.E., et al., The expression and function of microRNAs in chondrogenesis and osteoarthritis. Arthritis Rheum, 2012. 64(6): p. 1909-19. 
61. Li, L., et al., Elevated expression of microRNA-30b in osteoarthritis and its role in ERG regulation of chondrocyte. Biomedicine \& Pharmacotherapy, 2015. 76: p. 94-99.

62. Li, L., et al., MicroRNA-16-5p Controls Development of Osteoarthritis by Targeting SMAD3 in Chondrocytes. Curr Pharm Des, 2015. 21(35): p. 5160-7.

63. Yamasaki, K., et al., Expression of MicroRNA-146a in osteoarthritis cartilage. Arthritis Rheum, 2009. 60(4): p. 1035-41.

64. Weber, J.A., et al., The MicroRNA Spectrum in 12 Body Fluids. Clinical chemistry, 2010. 56(11): p. 1733-1741.

65. Makarova, J.A., et al., Intracellular and extracellular microRNA: An update on localization and biological role. Progress in Histochemistry and Cytochemistry, 2016. 51(3): p. 33-49.

66. Turchinovich, A., et al., Characterization of extracellular circulating microRNA. Nucleic Acids Research, 2011. 39(16): p. 7223-7233.

67. Murata, K., et al., Plasma and synovial fluid microRNAs as potential biomarkers of rheumatoid arthritis and osteoarthritis. Arthritis Research \& Therapy, 2010. 12(3): p. R86.

68. Kolhe, R., et al., Gender-specific differential expression of exosomal miRNA in synovial fluid of patients with osteoarthritis. Scientific Reports, 2017. 7(1): p. 2029.

- This study demonstrates the examination of extracellular vesicles from synovial fluid for aberrant miRNA expression. A down-regulated expression of miRNAs in extracellular vesicles from the synovial fluid of female knee OA patients was observed.

69. Li, Y.H., et al., Identification of synovial fluid microRNA signature in knee osteoarthritis: differentiating early- and late-stage knee osteoarthritis. Osteoarthritis and Cartilage, 2016. 24(9): p. 1577-1586.

70. Si, H., et al., Expression of miRNA-140 in Chondrocytes and Synovial Fluid of Knee Joints in Patients with Osteoarthritis. Chin Med Sci J, 2016. 31(4): p. 207-212.

71. Beyer, C., et al., Signature of circulating microRNAs in osteoarthritis. Annals of the Rheumatic Diseases, 2015. 74(3): p. e18.

72. Borgonio Cuadra, V.M., et al., Altered Expression of Circulating MicroRNA in Plasma of Patients with Primary Osteoarthritis and In Silico Analysis of Their Pathways. PLoS ONE, 2014. 9(6): p. e97690.

73. Kong, R., et al., Combination of circulating miR-19b-3p, miR-122-5p and miR-486-5p expressions correlates with risk and disease severity of knee osteoarthritis. Am J Transl Res, 2017. 9(6): p. 2852-2864.

74. Okuhara, A., et al., Changes in microRNA expression in peripheral mononuclear cells according to the progression of osteoarthritis. Modern Rheumatology, 2012. 22(3): p. 446-457.

75. Ponting, C.P., P.L. Oliver, and W. Reik, Evolution and Functions of Long Noncoding RNAs. Cell. 136(4): p. 629-641. 
76. Peschansky, V.J. and C. Wahlestedt, Non-coding RNAs as direct and indirect modulators of epigenetic regulation. Epigenetics, 2014. 9(1): p. 3-12.

77. Wang, K.C. and H.Y. Chang, Molecular mechanisms of long noncoding RNAs. Molecular cell, 2011. 43(6): p. 904-914.

78. Mattick, J.S. and J.L. Rinn, Discovery and annotation of long noncoding RNAs. Nat Struct Mol Biol, 2015. 22(1): p. 5-7.

79. Zhang, C., et al., Upregulation of IncRNA HOTAIR contributes to IL-1beta-induced MMP overexpression and chondrocytes apoptosis in temporomandibular joint osteoarthritis. Gene, 2016. 586(2): p. 248-53.

80. Chen, W.K., et al., IncRNAs: novel players in intervertebral disc degeneration and osteoarthritis. Cell Prolif, 2017. 50(1).

81. Wang, W.-T., et al., Genome-wide Long Non-coding RNA Analysis Identified Circulating LncRNAs as Novel Non-invasive Diagnostic Biomarkers for Gynecological Disease. Scientific Reports, 2016. 6: p. 23343.

82. Yan, Y., et al., Circulating Long Noncoding RNA UCA1 as a Novel Biomarker of Acute Myocardial Infarction. BioMed Research International, 2016. 2016: p. 8079372.

83. Song, J., et al., PBMC and exosome-derived Hotair is a critical regulator and potent marker for rheumatoid arthritis. Clin Exp Med, 2015. 15(1): p. 121-6.

84. Kishore, S., et al., Insights into snoRNA biogenesis and processing from PAR-CLIP of snoRNA core proteins and small RNA sequencing. Genome Biology, 2013. 14(5): p. R45.

85. Stepanov, G.A., et al., Regulatory Role of Small Nucleolar RNAs in Human Diseases. BioMed Research International, 2015. 2015: p. 10.

86. Zhang, L., et al., Serum non-coding RNAs as biomarkers for osteoarthritis progression after ACL injury. Osteoarthritis Cartilage, 2012. 20(12): p. 1631-7.

•• This study demonstrates the use of measuring snoRNAs one year following ACL injury and correlation with cartilage damage. A potential method for identifying extracellular genomic biomarkers associated with injury-induced OA.

87. Steinbusch, M.M.F., et al., Serum snoRNAs as biomarkers for joint ageing and post traumatic osteoarthritis. Scientific Reports, 2017. 7: p. 43558.

88. Fleischhacker, M., Circulating Nucleic Acids, in Encyclopedia of Cancer, M. Schwab, Editor. 2009, Springer Berlin Heidelberg: Berlin, Heidelberg. p. 695-697.

89. van der Vaart, M. and P.J. Pretorius, The Origin of Circulating Free DNA. Clinical Chemistry, 2007. 53(12): p. 2215-2215.

90. Tzimagiorgis, G., et al., Recovering circulating extracellular or cell-free RNA from bodily fluids. Vol. 35. 2011. 580-9.

91. Ma, X., et al., Cell-Free DNA Provides a Good Representation of the Tumor Genome Despite Its Biased Fragmentation Patterns. PLoS ONE, 2017. 12(1): p. e0169231. 
92. Chang, C.P.Y., et al., Elevated cell-free serum DNA detected in patients with myocardial infarction. Clinica Chimica Acta, 2003. 327(1): p. 95-101.

93. Gornik, I., et al., Free serum DNA is an early predictor of severity in acute pancreatitis. Clinical Biochemistry, 2009. 42(1): p. 38-43.

94. Abdelal, I.T., et al., Levels of plasma cell-free DNA and its correlation with disease activity in rheumatoid arthritis and systemic lupus erythematosus patients. The Egyptian Rheumatologist, 2016. 38(4): p. 295-300.

95. Schwarzenbach, H., D.S.B. Hoon, and K. Pantel, Cell-free nucleic acids as biomarkers in cancer patients. Nat Rev Cancer, 2011. 11(6): p. 426-437.

96. Leon, S.A., et al., DNA in synovial fluid and the circulation of patients with arthritis. Arthritis Rheum, 1981. 24(9): p. 1142-50.

97. Hashimoto, T., et al., Circulating cell free DNA: a marker to predict the therapeutic response for biological DMARDs in rheumatoid arthritis. International Journal of Rheumatic Diseases, 2017. 20(6): p. 722-730.

98. Hwang, H.S. and H.A. Kim, Chondrocyte Apoptosis in the Pathogenesis of Osteoarthritis. International Journal of Molecular Sciences, 2015. 16(11): p. 26035-26054.

99. Lichtenstein, A.V., et al., Circulating Nucleic Acids and Apoptosis. Annals of the New York Academy of Sciences, 2001. 945(1): p. 239-249.

100. Kleiveland, C.R., Peripheral Blood Mononuclear Cells, in The Impact of Food Bioactives on Health: in vitro and ex vivo models, K. Verhoeckx, et al., Editors. 2015, Springer International Publishing: Cham. p. 161-167.

101. Kato, K. and A. Radbruch, Isolation and characterization of CD34+ hematopoietic stem cells from human peripheral blood by high-gradient magnetic cell sorting. Cytometry, 1993. 14(4): p. 384-392.

102. Kon, et al., In-Depth Profiling of the Peripheral Blood Mononuclear Cells Proteome for Clinical Blood Proteomics. International Journal of Proteomics, 2014. 2014: p. 9.

103. Sokolove, J. and C.M. Lepus, Role of inflammation in the pathogenesis of osteoarthritis: latest findings and interpretations. Therapeutic Advances in Musculoskeletal Disease, 2013. 5(2): p. 77-94.

104. Haseeb, A. and T.M. Haqqi, Immunopathogenesis of Osteoarthritis. Clinical immunology (Orlando, Fla.), 2013. 146(3): p. 185-196.

105. Ponchel, F., et al., Changes in peripheral blood immune cell composition in osteoarthritis. Osteoarthritis and Cartilage, 2015. 23(11): p. 1870-1878.

106. Marshall, K.W., et al., Blood-based biomarkers for detecting mild osteoarthritis in the human knee. Osteoarthritis and Cartilage, 2005. 13(10): p. 861-871.

107. Ramos, Y.F.M., et al., Genes expressed in blood link osteoarthritis with apoptotic pathways. Annals of the Rheumatic Diseases, 2014. 73(10): p. 1844. 
108. Attur, M., et al., Increased IL-1 beta gene expression in peripheral blood leukocytes is associated with increased pain and predicts risk for progression of symptomatic knee osteoarthritis. Arthritis and rheumatism, 2011. 63(7): p. 1908-1917.

109. Korosty, et al., Blood Transcriptional Signatures for Disease Progression in a Rat Model of Osteoarthritis. International Journal of Genomics, 2017. 2017: p. 7.

110. Jeffries, M., et al., A differential peripheral blood DNA methylation pattern predictive of radiographic OA progression. Osteoarthritis and Cartilage, 2016. 24(Supplement 1): p. S230S231.

111. Izzotti, A., et al., Extracellular MicroRNA in liquid biopsy: applicability in cancer diagnosis and prevention. American Journal of Cancer Research, 2016. 6(7): p. 1461-1493.

112. Di Meo, A., et al., Liquid biopsy: a step forward towards precision medicine in urologic malignancies. Molecular Cancer, 2017. 16(1): p. 80.

113. Review, M.T. 10 Breakthrough Technologies 2015. 2015; Available from: https://www.technologyreview.com/lists/technologies/2015/.

•• In 2015 the MIT Technology Review listed liquid biopsy as a top ten technology breakthrough. In the future, with the identification of a soluble biomarker for OA, liquid biopsies could be utilised in the screening and monitoring of $\mathrm{OA}$.

114. Sheridan, C., Exosome cancer diagnostic reaches market. Nat Biotechnol, 2016. 34(4): p. 35960.

115. McKiernan, J., et al., A novel urine exosome gene expression assay to predict high-grade prostate cancer at initial biopsy. JAMA Oncology, 2016. 2(7): p. 882-889.

116. Starling, R.C., et al., Molecular Testing in the Management of Cardiac Transplant Recipients: Initial Clinical Experience. The Journal of Heart and Lung Transplantation. 25(12): p. 13891395.

117. Bloom, R.D., et al., Cell-Free DNA and Active Rejection in Kidney Allografts. J Am Soc Nephrol, 2017. 28(7): p. 2221-2232.

118. Akers, J.C., et al., Biogenesis of extracellular vesicles (EV): exosomes, microvesicles, retrovirus-like vesicles, and apoptotic bodies. Journal of neuro-oncology, 2013. 113(1): p. 111.

119. Feingold, K.R. and C. Grunfeld, Introduction to lipids and lipoproteins. 2015.

120. Vickers, K.C., et al., MicroRNAs are Transported in Plasma and Delivered to Recipient Cells by High-Density Lipoproteins. Nature cell biology, 2011. 13(4): p. 423-433.

121. Arroyo, J.D., et al., Argonaute 2 complexes carry a population of circulating microRNAs independent of vesicles in human plasma. Proceedings of the National Academy of Sciences, 2011. 108(12): p. 5003-5008. 
122. Winter, J. and S. Diederichs, Argonaute proteins regulate microRNA stability: Increased microRNA abundance by Argonaute proteins is due to microRNA stabilization. RNA Biology, 2011. 8(6): p. 1149-1157.

123. Nakanishi, K., Anatomy of RISC: how do small RNAs and chaperones activate Argonaute proteins? Wiley Interdisciplinary Reviews: RNA, 2016. 7(5): p. 637-660.

124. Nassar, W., et al., Extracellular Micro-RNAs in Health and Disease: Basic Science, Biogenesis and Release. American Journal of Molecular Biology, 2016. Vol.06No.01: p. 11.

125. Turchinovich, A., L. Weiz, and B. Burwinkel, Extracellular miRNAs: the mystery of their origin and function. Trends in Biochemical Sciences, 2012. 37(11): p. 460-465.

126. Strimbu, K. and J.A. Tavel, What are Biomarkers? Current opinion in HIV and AIDS, 2010. 5(6): p. 463-466.

127. Chu, C.R., et al., Early diagnosis to enable early treatment of pre-osteoarthritis. Arthritis Research \& Therapy, 2012. 14(3): p. 212.

128. Ickinger, C. and M. Tikly, Current approach to diagnosis and management of osteoarthritis. South African Family Practice, 2014. 56(2): p. 102-108.

129. Lotvall, J., et al., Minimal experimental requirements for definition of extracellular vesicles and their functions: a position statement from the International Society for Extracellular Vesicles. J Extracell Vesicles, 2014. 3: p. 26913.

130. Melo, S.A., et al., Cancer exosomes perform cell-independent microRNA biogenesis and promote tumorigenesis. Cancer Cell, 2014. 26(5): p. 707-21.

131. Lee, Y., S. El Andaloussi, and M.J.A. Wood, Exosomes and microvesicles: extracellular vesicles for genetic information transfer and gene therapy. Human Molecular Genetics, 2012. 21(R1): p. R125-R134.

132. Chan, I.S. and G.S. Ginsburg, Personalized medicine: progress and promise. Annu Rev Genomics Hum Genet, 2011. 12: p. 217-44.

133. Agarwal, A., D. Ressler, and G. Snyder, The current and future state of companion diagnostics. Pharmacogenomics and Personalized Medicine, 2015. 8: p. 99-110.

134. Bay-Jensen, A.-C., et al., The Need for Predictive, Prognostic, Objective and Complementary Blood-Based Biomarkers in Osteoarthritis (OA). EBioMedicine, 2016. 7: p. 4-6.

135. Wang, Z., et al., Telomeric repeat-containing RNA (TERRA) constitutes a nucleoprotein component of extracellular inflammatory exosomes. Proceedings of the National Academy of Sciences, 2015. 112(46): p. E6293-E6300.

136. Dirks, R.A.M., H.G. Stunnenberg, and H. Marks, Genome-wide epigenomic profiling for biomarker discovery. Clinical Epigenetics, 2016. 8(1): p. 122.

137. Altman, R., et al., Development of criteria for the classification and reporting of osteoarthritis. Classification of osteoarthritis of the knee. Diagnostic and Therapeutic Criteria Committee of the American Rheumatism Association. Arthritis Rheum, 1986. 29. 
138. Marshall, K.W., The case for a simple method of grading osteoarthritis severity at arthroscopy. J Rheumatol, 1996. 23(4): p. 582-5.

139. Mullany, L.E., et al., MicroRNA Seed Region Length Impact on Target Messenger RNA Expression and Survival in Colorectal Cancer. PLoS ONE, 2016. 11(4): p. e0154177.

140. Kung, J.T.Y., D. Colognori, and J.T. Lee, Long Noncoding RNAs: Past, Present, and Future. Genetics, 2013. 193(3): p. 651-669.

141. Valadkhan, S. and L.S. Gunawardane, Role of small nuclear RNAs in eukaryotic gene expression. Essays In Biochemistry, 2013. 54: p. 79.

142. Matera, A.G. and Z. Wang, A day in the life of the spliceosome. Nature Reviews Molecular Cell Biology, 2014. 15: p. 108.

143. Martens-Uzunova, E.S., M. Olvedy, and G. Jenster, Beyond microRNA - Novel RNAs derived from small non-coding RNA and their implication in cancer. Cancer Letters, 2013. 340(2): p. 201-211.

144. Taft, R., et al., Small RNAs derived from snoRNAs. RNA, 2009. 15.

145. Scott, M.S. and M. Ono, From snoRNA to miRNA: dual function regulatory non-coding RNAs. Biochimie, 2011. 93.

146. Randau, L. and D. Söll, Transfer RNA genes in pieces. EMBO Reports, 2008. 9(7): p. 623-628.

147. Lodish H, B.A., Zipursky SL, et al., Molecular Cell Biology. 4th Edition. ed. 2000, New York: W. H. Freeman; 2000.

148. Diebel, K.W., et al., Beyond the Ribosome: Extra-translational Functions of tRNA Fragments. Biomarker Insights, 2016. 11(Suppl 1): p. 1-8.

149. Moore, P.B. and T.A. Steitz, The Roles of RNA in the Synthesis of Protein. Cold Spring Harbor Perspectives in Biology, 2011. 3(11): p. a003780.

150. Greene, J., et al., Circular RNAs: Biogenesis, Function and Role in Human Diseases. Frontiers in Molecular Biosciences, 2017. 4: p. 38.

151. Meng, S., et al., CircRNA: functions and properties of a novel potential biomarker for cancer. Molecular Cancer, 2017. 16: p. 94.

152. Iwasaki, Y.W., M.C. Siomi, and H. Siomi, PIWI-Interacting RNA: Its Biogenesis and Functions. Annual Review of Biochemistry, 2015. 84(1): p. 405-433.

153. Weick, E.-M. and E.A. Miska, piRNAs: from biogenesis to function. Development, 2014. 141(18): p. 3458.

154. Stadler, P.F., et al., Evolution of Vault RNAs. Molecular Biology and Evolution, 2009. 26(9): p. 1975-1991.

155. Amort, M., et al., Expression of the vault RNA protects cells from undergoing apoptosis. Nature Communications, 2015. 6: p. 7030.

156. Köhn, M., N. Pazaitis, and S. Hüttelmaier, Why YRNAs? About Versatile RNAs and Their Functions. Biomolecules, 2013. 3(1). 
